\title{
İngiliz Belgelerine Göre Türkiye'de 1960, 1971 ve 1980 Askeri Müdahaleleri
}

\author{
Behçet Kemal Yeşilbursa* \\ (ORCID ID: 0000-0001-6309-5703) \\ Makale Gönderim Tarihi \\ 07.02.2019 \\ Makale Kabul Tarihi \\ 04.03.2019
}

\section{Özet}

Bu makalede Türkiye'deki 1960, 1971 ve 1980 askeri müdahaleleri incelenmektedir. Makalede orduyla hükümet arasındaki ilişkiyi analiz etmek, ordunun Türkiye siyasetine ne ölçüde müdahale ettiğini belirlemek, Cumhuriyet'in gelişmesinde oynamış olduğu rolü incelemek de hedeflenmektedir. Burada asıl amacımı darbelerin neden yapıldığını, Britanya'nın görüşünün ve devrimden sonra istikrar beklentilerinin neler olduğunu tartışmaktır.

Ordu, modern Türkiye'nin siyasi tarihinde önemli bir yere sahiptir. Her on yılda bir adeta düzenli olarak yapılan askeri darbeler, bunun kanıtı gibi görünüyor. Mayıs 1960, Mart 1971 ve Eylül 1980'deki müdahaleler, silahlı kuvvetlerin cumhuriyetin demokratik egemenliğini, yolsuz ve beceriksiz politikacıların yaptıkları işleri takiben, geri getirme eylemleri olarak açıklandı. Ordu, 1960'da Adnan Menderes'in Demokrat Parti hükümetini, eylemlerini haklı çıkarmak için meclisteki ezici çoğunluğuna güvenerek anayasayı tamamen göz ardı ederek ülkeyi yönettiği gerekçesiyle devirdi. Mart 1971'de ordu, Süleyman Demirel'i istifaya zorladı ve on yıl sonra Eylül 1980'de aynısını yaptı. Illk müdahale anayasanın savunulması olarak haklı gösterildi. Diğer iki darbenin sebebi hükümetlerin zayıf, verimsiz, anarşi ve istikrarsızlığın kaynağı olarak gösterildi. Her defasında ordu, politikacıları kendi yaptıkları karışıklıktan kurtarmak için müdahale ettiğini iddia etti. Türk ordusu cumhuriyetin koruyucusu ve Kemalist mirasın devamı olarak algılanırsa, darbe olasılığı her zaman var olacaktır. Ancak, iktidar seçkinlerinin en azından bir kısmının, nüfusun önemli kesimlerine ek olarak, ordu yönetiminin krizden çıkışı tek yol olduğuna inandıkları ve bunun için davet edildiğine bakarak ordunun müdahale etmek için her zaman güce sahip olduğunu vurgulamalıyız.

Anahtar Kelimeler: Darbeler, 1960 Darbesi, 1971 Müdahalesi, 1980 Darbesi, Ordu, Türkiye.

* Prof. Dr., Uludağ Üniversitesi, Fen-Edebiyat Fakültesi, Tarih Bölümü, bkyesilbursa@uludag.edu.tr.

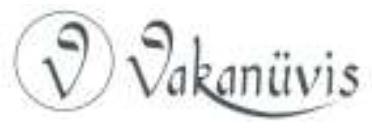




\title{
The Military Interventions of 1960, 1971 and 1980 in Turkey according to British Documents
}

\begin{abstract}
The military has had a significant role in the political history of modern Turkey. The seemingly regular military takeovers, each a decade apart, act as proof of this. The interventions in May 1960, March 1971, and September 1980 have been explained as the reluctant acts of the armed forces to set the democratic rule of the republic back on its original tracks following the deeds of corrupt and incompetent politicians. In 1960, the army ousted the Democrat Party government of Adnan Menderes on the grounds that he ran the country with total disregard for the constitution, relying on his overwhelming majority in parliament to justify his actions. In March 1971, the military forced the resignation of Süleyman Demirel, and did so again ten years later, in September 1980. The first intervention was justified as defence of the constitution. On the other two occasions, the governments were deemed weak and inefficient, the source of anarchy and instability which threatened the very foundation of the state of which the armed forces were the guardians. On each occasion the army claimed that it had intervened only to remove the politicians from the mess they themselves had made. The possibility of another coup is always present so long as the Turkish army perceives itself as the guardian of the republic and its Kemalist legacy. However, it must be emphasised that the army has only ever seized power when at least part of the ruling elite, in addition to substantial parts of the population, have come to believe that military rule is the only way out of the crisis and virtually invited the army to intervene.
\end{abstract}

Keywords: Coups, 1960 Coup, 1971 Intervention, 1980 Coups, Military, Turkey.

\section{Giriş}

1960, 1971 ve 1980 darbeleri istisnai birer askeri eylem olarak düşünülemez; ordunun ülkenin işlerine müdahil olması Osmanlı dönemine tarihlenen eski bir gelenekten kaynaklanır. Modern Türk tarihinde askerin siyasete müdahalesi genellikle ilerici ve reformistti. 19. yüzyılda Osmanlı ordusunun Avrupa örneklerine göre yeniden düzenlenmesi ve Batı'dan askeri danışmanların ithali sonucunda subaylar Türkiye'de en Batılılaşmış unsurlardan biri haline geldi. Zira Sultan Abdülhamid (1876-1909) Batılılaşma çabalarını birçok alanda durdururken orduda devam etmesine izin vererek subayları sosyal

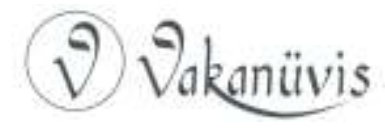


değişimde ön plana çıkardı. Nitekim askeri diktatörlüğe dönüştüğü 1911'e kadar kısa süreliğine Türkiye'de anayasal hükümetin yeniden kurulduğu 1908 Genç (Jön) Türkler Devrimi'nde subaylar önemli rol oynadılar. 1911'den başlayarak yedi yıl neredeyse kesintisiz devam eden düşmanlıklar dâhil, (1908'den 1918'e kadar süren on yılda) ordu siyaset sahnesinde nüfuzlu bir unsur olarak yer aldı. 1918'de Osmanlı Imparatorluğu'nun yenilmesi ve arkasından Müttefiklerle Yunanlıların müdahalesi ordunun önemini iyice vurguladı. Ülkede başka hiçbir kurum böyle her yönüyle örgütlü, ilerici ve milliyetçi değildi. Sonuçta, ordu ülkenin parçalanmasının önlenmesine liderlik ederek, 1923'te Türkiye Cumhuriyeti'nin kurulmasında Mustafa Kemal Atatürk'ün temel desteği oldu. ${ }^{1}$

1923'te Cumhuriyet'in kuruluşunda Atatürk'ün başlıca desteği orduydu, ordu onun geniş kapsamlı reformlarını destekledi, yerleştirdiği sivillerin üstünlüğü geleneğini kabul etti, ona ve halefi İsmet İnönü'ye sadık kaldı. Yine de, 1946'dan sonra şikâyete yol açan bazı durumlar askerin, İnönü'den ve onun Cumhuriyet Halk Partisi'ndense (CHP) yeni kurulan Demokrat Parti'yi (DP), sivillere yönelik doğasına rağmen, desteklemesine neden oldu. 1950-1960 yılları arasında Demokrat Parti birtakım icraatlarıyla Silahlı Kuvvetleri soğuttu. Özellikle, görüşlerini önemsemedi, ordunun standardını yükseltemedi, Atatürk'ün modernleştirme hedeflerinden ve ideallerinden giderek saptı, pervasız ekonomi politikalarını benimsedi ve demokratik süreçleri göz ardı etti. 1960 darbesi askerin birkaç yıllık komplosunun sonucuydu ve DP'nin demokrasi dışı yollarla görev süresini süresiz olarak uzatma niyetinin belli olması bunu tetikledi. Askerin siyasete doğrudan müdahale dönemi sadece 17 ay sürdü. Silahlı Kuvvetler, devrimci subaylardan oluşan Milli Birlik Komitesi'yle yönetti, çok geçmeden Komite ılımlı ve radikal gruplar olarak ikiye bölündü, ilk söz edilen ancak DP ağır şekilde bastırıldıktan sonra 1961 Ekim'inde sivil hükümete dönüşü güvence altına almayı başardı. Askeri yönetimin ardından Silahlı Kuvvetlerin nüfuzu eskisinden daha fazlaydı ve siyasetçilerle daha yakın temastaydı. Sivil hükümete dönüşü doğru bulmayan askeri unsurlar 1962 ve 1963'te başka iki darbeye daha

1 FCO51/95/RR6/9, The Role of the Armed Forces in Turkish Politics, 5 Eylül 1969. Feroz Ahmad, The Making of Modern Turkey, Londra, 1993, s. 1-14.

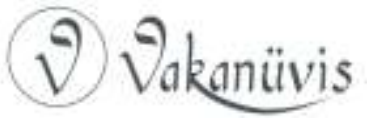


kalkıştılar. Ne var ki huzursuzluk belirtileri sonradan giderek azaldı ve 1960 ’ların sonunda asker siyaset dışı geleneksel rolüne büyük ölçüde geri döndü. ${ }^{2}$

Cumhuriyet'in ilk günlerinde sivil ve askeri işleri ayırmak için büyük çaba gösterilmedi, subaylar ülke yönetimine aktif olarak katıldılar. Yine de, askeri zafer güvence altına alınır alınmaz Atatürk sivil ve askeri sektörler arasında net ayrımın arzu edilebilirliği konusunda daha 1909 'da ifade ettiği görüşlerini yürürlüğe koymaya başladı. Geçmişe bakıldığında, Atatürk'ün, iktidarı için askerin siyasal desteğinin artık vazgeçilmez olmadığı anda onu aktif siyasal yaşamın dışında tutmak için bilerek çaba gösterdiği bellidir. Başarılı birer askeri lider olan Atatürk ve halefi İsmet İnönü, ülkeyi askeri yöneticiler yerine sivil olarak yönetmeyi seçtiler, Cumhuriyet Halk Partisi'nden (CHP), Büyük Millet Meclisi'nden ve zamanla bürokrasiden destek aldılar. Baş mimarları oldukları Cumhuriyet Anayasası'nda asker sivil iktidarın gerisindeydi. Subayların Parlamento üyesi olarak aktif görev almalarını yasaklayan Aralık 1924 tarihli Millet Meclisi kararıyla askerin siyasal faaliyetten resmen uzak tutulması güvence altına alındı. Atatürk sosyal, siyasal ve ekonomik reformlara fon aktarmak için askeri bütçeleri azaltarak ordunun önemini de azalttı. ${ }^{3}$

Pratikte askeri ve sivil alanların ayrılması asla tamamlanmadı veya su geçirmez değildi. Atatürk askere "ilerici uygulamaların kaynağı" rolünü öngördü, reformlarını halka asker yayacaktı. 1931'de Konya'da askeri rejimin "Kemalizm'in Altı Oku" diye bilinen Cumhuriyetçilik, Milliyetçilik, Halkçllık, Devletçilik, Laiklik ve Reformculuk ideallerinin "bekçisi" olarak tanımladı. ${ }^{4}$

Dolayısıyla, Silahlı Kuvvetler siyasetten tamamıyla dışlanamadı, gerçi Atatürk'ün niyeti daha çok, kendisinin çabalarını desteklemek için onların son çare olarak doğrudan devreye girerek, kendisine, cumhuriyete ve reformlarına sadık kalmalarını sağlama almaktı. Eski subayların bakanlık, parlamento ve yönetim kademelerinde önemli

\footnotetext{
2 FCO51/95/RR6/9, The Role of the Armed Forces in Turkish Politics, 5 Eylül 1969.

${ }^{3}$ FCO51/95/RR6/9, The Role of the Armed Forces in Turkish Politics, 5 Eylül 1969. Ümit Özdağ, Atatürk ve Inönü Dönemlerinde Türk Silahlı Kuvvetleri, Ankara, 2017, s. 25-87.

${ }^{4}$ FCO51/95/RR6/9, The Role of the Armed Forces in Turkish Politics, 5 Eylül 1969. Ahmad, a.g.e., s. 1-14.
}

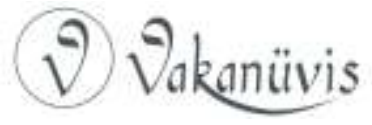


siyasi makamlara gelmeleriyle askerin nüfuzu sivil alanda hissedildi; gerçi 1960'ların sonunda bu giderek azalmıştı. ${ }^{5}$ Türkiye Cumhuriyeti'nin sivil hükümetleri askerlikte edinilen yöneticilik yeteneklerinden yararlanmakta tereddüt etmedi, yine de Atatürk'ün sivillerin üstünlüğü geleneği 1960'a kadar asker fiili bir engel çıkarmadan sürdü. ${ }^{6}$

1945'e kadar Atatürk'ün Cumhuriyet Halk Partisi (CHP), Cumhuriyet'te (kısa ömürlü iki istisna dışında) var olmasına izin verilen tek partiyken askerin rejime desteğini sürdürmesi güç değildi. Atatürk'ün ağır basan kişiliği 1938'de ölümüne kadar ordunun pasifliğini garanti altına aldı, yardımcısı ve halefi İsmet İnönü’nün de benzer şekilde askerin sadakatinde büyük etkisi vardı. Üstelik ordu hükümetin reformlarını gerçekten onaylıyor, yönetimdeki partiyle kökleri İstiklal Savaşı'na ve Cumhuriyet'in ilk günlerine giden ortak bir tarihi paylaşıyordu. Hükümet CHP'ye alternatif siyasi partilerin var olması yasağını gevşettikten sonra, 1946 Ocak'ında kurulan Demokrat Parti'yle böyle ortak bir mirası paylaşmıyordu. Demokrat Parti'nin askeri olmayan, tamamıla sivil bir karakteri vardı. İki avukat, yani Adnan Menderes'le Refik Koraltan, Profesör Mehmet Fuad Köprülü, bankacı ve iktisatçı Celal Bayar tarafından kuruldu. Hepsi CHP'nin muhalif üyeleriydi ve sadece son adı geçen İstiklal Savaşı'nda rol oynamıştı. $^{7}$

Demokrat Parti'nin seçim başarısı başlangıçta sınırlıydı, nedeni kısmen hazırlıksız olması, kısmen de CHP'nin seçimleri kötü yönetmesiydi. CHP'nin 1946 seçimlerini yürütme tarzı 10 kurmay albayla binbaşının hükümeti devirmenin kendi görevleri olduğuna

${ }^{5}$ FCO51/95/RR6/9, The Role of the Armed Forces in Turkish Politics, 5 Eylül 1969. 1920'de Büyük Millet Meclisi'nde eski subayların oranı altıda bir, 1943'te hâlâ sekizde birdi ama Demokratik Parti 1950 seçiminde galip geldikten sonra yirmide bire, 1958' de yirmi beşte bire düştü. 1923-1955 yılları arasında askerlikten gelenler Cumhurbaşkanı (27 yıl), Başbakan (16,5 yıl), Savunma Bakanı (16,5 yıl), Bayındırlık Bakanı (15 yıl), Ulaştırma Bakanı (9 yıl) olarak ve kabinede başka makamlarda hizmet verdiler. Eski subayların yer almadığı ilk bakanlık 1948'de Hasan Saka'nınkiydi. Ayrıca valilerin çoğu asker kökenliydi.

${ }^{6}$ FCO51/95/RR6/9, The Role of the Armed Forces in Turkish Politics, 5 Eylül 1969. Ahmad, a.g.e., s. 1-14.

7 FCO51/95/RR6/9, The Role of the Armed Forces in Turkish Politics, 5 Eylül 1969. Özdağ, Atatürk ve Inönü, s. 133-193.

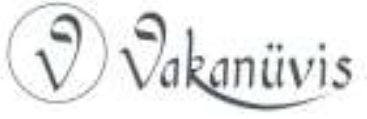


karar vermesine neden oldu. Destek için Gelibolu'da Kolordu Komutanı General Fahri Belen'e yanaştılar ama komutan onlara gelecek seçimlere kadar beklemelerini tavsiye etti. DP'yi ezici oy üstünlüğüyle kazandığı zaferle iktidara getiren, gerçekten özgür ve dürüst 1950 seçimleri oldu. DP onlarca yıldır CHP yönetimine duyulan hoşnutsuzluktan yararlandı. Aslında, DP'yi destekleyen herkesi sadece Cumhuriyetçilere muhalefet bir araya getirdi. Nitekim iş adamları, toprak sahipleri, köylüler, işçiler, entelektüeller ve geleneklerine bağı muhafazakârların hepsi genelde böyle grup oluşturabildi. ${ }^{8}$

Kendi şikâyet listelerini biriktiren bürokrasi ve asker de DP'yi destekledi. Ordu İstiklal Savaşı'ndan galip çıkmıştı; ne var ki 1923'ten başlayarak eski olağanüstü önemli konumunu kaybetmeye başladı. Çağdışıydı, gereğinden çok kalabalıktı, yeniden örgütlenmeye ve yeniden donatıma çok ihtiyacı vardı, kötü besleniyor, yetersiz giyiniyor ve kötü eğitiliyordu. Sivil hiyerarşi yeni fikirler ve taze kan edinirken asker hiç ilerlemiyordu. Amerika Birleşik Devletleri'nin 1948'de başlayan askeri yardım programı Türk Silahlı Kuvvetleri için yeni bir dönemin başlangıcını belirtiyordu ama sivil denetimin gerisinde kalmaya hâlâ devam ediyordu. Hem CHP hem DP eski ordudan adaylar yazarak askerin tarafını tutmaya çalışmakla birlikte, iki parti de gerçekte askerlik kurumunu daha da geriletmeyi hedefliyordu. DP'nin sivil yönelimi belliydi. Bu arada, 1949 Mayıs'ında CHP daha güçlü bir sivil yönetimi güvence altına alarak, Genel Kurmayı Savunma Bakanlığının denetimine verdi ve bütün savunma konularında koordinasyonu sağlamak için Milli Savunma Konseyi'ni kurdu. ${ }^{9}$

Subayların Batı ordularının standartlarıyla kendilerininki arasındaki uçurumu fark etmeleri CHP'ye içerlemelerine yol açtı, Amerika Birleşik Devletleri askeri yardım misyonu subaylarıyla temasları bunu daha da alevlendirdi. Subay sınıfında sivil emsallerinin entelektüel hoşnutsuzluğunu paylaşan çok kişi vardı ve Türkiye için yeni bir demokratik çağ vaadinde bulunan DP’nin yükselişini iyi karşıladılar. Konumları gereği siyasetten uzak dururken, CHP'nin Atatürk'ün

8 FCO51/95/RR6/9, The Role of the Armed Forces in Turkish Politics, 5 Eylül 1969. Özdağ, Atatürk ve Inönü, s. 133-193.

9 FCO51/95/RR6/9, The Role of the Armed Forces in Turkish Politics, 5 Eylül 1969. Özdağ, Atatürk ve Inönü, s. 133-193.

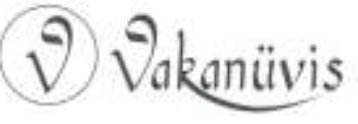


ölümünden sonra ve savaş sırasında benimsediği giderek artan sıkı önlemlerin ve 1946 seçimlerini adaletsiz yönetmesinin uyandırdığı subaylar da vardı. DP'nin zaferine iyimserlikle bakıyorlardı. Bu subaylar, yakın zamanda kaybettiği özsaygıyı askerin yeniden kazanabileceği ve iktidarın üst düzeylerinde nüfuzlarının bir ölçüde artmasıyla subay sınıfının desteğinin ödüllendirileceği yeni bir demokrasi çağı beklentisiyle gruplarını tasfiye ettiler. ${ }^{10}$ DP'nin 1946'da kurulması ve 1950 zaferi Türkiye'de siyasal arenada radikal bir değişiklik yaptı. Seçmen ilk kez bağımsız oldu ve iki parti oy kazanmaya çalışırken, ordunun görüşleriyle halka manda uygulayan sivil yönetimin görüş ayrıı̆ı̆ı ilk kez ortaya çıktı. Sonuç, 1960 darbesi olacaktı.

1950-1960 yılları arasında Türkiye siyasetinde başlıca iki parti vardı. DP iktidarda, CHP ise muhalefetteydi. 1950 seçimlerinden ve iktidarın $\mathrm{CHP}^{\prime}$ den $\mathrm{DP}^{\prime}$ ye geçmesinden hemen sonra kısa ömürlü bir siyasal balayı yaşandı. Birkaç yıl rejim Türkiye'nin pek görmediği kadar liberaldi. DP'nin birinci lideri Celal Bayar'ın belirttiği gibi, ideolojik farklar yoktu ve iki parti de kalkınma program, modern ve müreffeh Türkiye vaat ediyordu. Demokratlar bir kuşak zarfında her ilde bir milyonerle Türkiye'yi "küçük Amerika" yapma sözü veriyordu. Cumhuriyetçiler de benzer bir program izlemişlerdi. İki partinin hedefleri değil, yöntemleri farklıydı. Ne var ki DP önceki "geçmişi sorgulamayacağı" sözüne rağmen, çok geçmeden CHP’ye karşı basın ve radyo sansürü koymak gibi sıkı önlemlere başvurduğunda balayı çok uzun sürmedi. DP çok geçmeden CHP'ye açık saldırı başlattı. CHP'nin önemli miktarda mülküne, tek parti döneminde kamu fonlarını kötüye kullanılarak yasa dışı yollarla elde edildiği gerekçesiyle el konuldu. Yerel parti merkezleri kapatıldı. Yeni basın yasasıyla, Türkiye'nin istikrarını tehlikeye atabilecek asılsız haber yayınlanmasına ağır cezalar getirildi. ${ }^{11}$

1954 seçimlerinden sonra ekonomik durumun kötüye gitmesiyle beraber artan oy çoğunluğu, DP hükümetini, parti içinde eleştirilmesine rağmen, daha otoriter bir yönetime sevk etti. 1957

10 FCO51/95/RR6/9, The Role of the Armed Forces in Turkish Politics, 5 Eylül 1969. Özdağ, Atatürk ve Inönü, s. 133-193.

${ }^{11}$ Ahmad, a.g.e., s. 109-111. Roderic H. Davison, Turkey, A Short History, Huntington, 1988, s. 153.

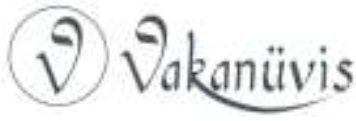


seçiminden sonra, parti içinde ilişkiler bozulurken siyasal gerilim durmadan arttı. Zafere ve Meclis'te daha çok temsil edilmeye susamış CHP, Başbakan Adnan Menderes'le arkadaşlarına sert eleştirilerini ve saldırılarının sıklığını artırdı. Hükümet, baskı eylemlerini sürdürerek karşılık verdi, parlamentonun içinde ve dışında şiddet tırmandı. CHP, DP'nin dış politikasını da şiddetle eleştirdi. Ne var ki CHP'nin dış politika eleştirisi büyük ölçüde meselelerin ayrıntılarında ve hükümetin politikasını yürütme tarzında odaklanıyordu, altında yatan stratejide değil. Çünkü CHP de savaş sonrası dönemde esas itibarıyla benzer bir dış politika izlemişti. ${ }^{12}$

\section{Mayıs 1960 Askeri Darbesi}

Türkiye için 1960 hem iç hem de dışişlerinde önemli ve dramatik gelişmelere sahne olacaktı. Nitekim yıl, Demokrat Parti'yle (DP) Cumhuriyet Halk Partisi (CHP) arasında yüksek gerilimle başladı. 1960'ın sonu veya 1961'in başında seçim bekleniyordu. Dolayısıyla, siyasal spekülasyon hükümet 1960 ilkbaharında veya sonbaharında erken seçime gidecek mi, sorusunda odaklandı. Yasal olarak, 1961 başına kadar seçime gitmeleri gerekmiyordu. Ne var ki hükümet üyeleriyle destekçileri, tarih bildirmeye az bir zaman kala, seçimlerin 1960 yazından önce yapılacağı izlenimini uyandırmayı başardı. Bakanların ülkenin her yanına yaptıkları gezilerin belirgin özelliğini vaat edilen ekonomik kalkınmayı ve yeni seçim kütüklerinin hazırlanmasını içeren yaygaracı seçim propagandası konuşmaları oluşturuyordu. ${ }^{13}$

Başbakan Adnan Menderes erken seçime gitmekten yanaydı. Ne var ki başbakan parti meselelerinde nüfuzunu bir hayli bağımsız kullanan Cumhurbaşkanı Celal Bayar dâhil, partililerinden yeterli çoğunluğu ne yazık ki yanına çekemedi. Erken seçime muhalefet edenleri sonucun genelde belirsizliği motive etmiş olabilirdi ama büyük ihtimalle daha kişisel mülahazalar vardı. O dönemlerde parlamento üyeleri seçildikleri dört yıllık sürenin tamamı için aylıklarını önceden çekiyorlardı. Bu durumda, meclis dönem sonundan önce feshedilirse, teoride üyeler çektiklerinin uygun bir miktarını geri ödemek

\footnotetext{
12 Ahmad, a.g.e., s. 109-111. Davison, a.g.e., s. 153.

13 Cihat Göktepe, "1960 Revolution in Turkey and the British Policy towards Turkey", Turkish Yearbook of International Relations, (Ankara Üniversitesi, Siyasal Bilgiler Fakültesi), Vol. XXX, 2001, s. 158.
}

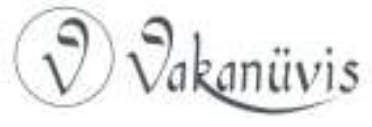


zorundaydılar. ${ }^{14}$ Üstelik bazı durumlarda, üye kendi partisinin seçileceğinden açıkça emin olsa bile, yerel rakipleri nedeniyle DP'den aday seçileceği konusunda kişisel kuşkular duyabiliyordu. Sonunda, Almanya'dan yeni alınan 50 milyon dolarlık yardımla hükümet yılın geri kalanını yeni bir ekonomik krize girmeksizin daha rahat geçirebileceğini düşünmüş olabilirdi. ${ }^{15}$

Britanya'nın Ankara Büyükelçisi Sir Bernard Burrows Türkiye'nin siyasal durumunu şu şekilde analiz etmişti:

"çok sayıda dış gözlemcinin, seçimin Demokratların bir zafer daha kazanmasına muhtemelen son vereceği görüşünde olduklarını belirtti." Yine de hükümet yılın başında ülkeye gitme riskini alamayacağına karara varmış gibi görünüyordu, çünkü ya başarısız olacaklardı ya da seçim karışıklığa yol açacak, ordu DP'nin lehine bunu bastırmak istemeyecekti. Kaybetme riskine girmemeye karar vermelerinin nedeni Başbakan Adnan Menderes'in kaderinin Türkiye'yi yeniden inşa etmek olduğuna dair neredeyse dinsel inancıydı, çünkü son zamanlarda kendisi ve partinin diğer liderleri bazı icraatlarını dostça olmayan bir yönetimin desteklemeyeceğini hissetmişlerdi." ${ }^{16}$

Dahası, muhalefetin eleştirisinden ve propagandasından oldukça rahatsız olmuşlardı, baskı yapmanın kısır döngüsüne girdiler. Aslında, iktidarı kaybetme düşüncesi onları son derece endişelendiriyordu, kaybetmeyi önlemek için aldıkları mantıksız tedbirlerle bu olayı hızlandırdılar. Siyasal fikirleri Türkiye'nin devrimci mücadelesinin ilk günlerinde oluşmuş ve gerçek bir demokrasi anlayışına asla evrilmemiş bazı üyeler tek parti yönetimini veya daha açıkçası diktatörlüğü yeniden uygulamaya koymayı düşünüyorlardı. ${ }^{17}$

Cumhurbaşkanı Celal Bayar'la parti kulisindekiler için, parlamento ve seçim yöntemi Balkan Savaşları'ndan ve İstiklal Savaşı'ndan bildikleri silahlı Komitacı çeteleri arasındaki mücadelenin dolambaçlı, yeni bir arka planından daha fazlasını sağlamıyordu. Yeni kurallar

14 FO371/153032/RK1015/10, Burrows'tan Britanya Dışişleri Bakanlığı'na (Selweyn Lloyd), Ankara, 22 Nisan 1960.

${ }^{15}$ Göktepe, a.g.m., s. 159.

16 FO371/160212/RK1011/1, Sir Bernard Burrows, "Annual Report on Turkey for 1960", Britanya Büyükelçiliği, Ankara, 6 Ocak 1961.

17 FO371/160212/RK1011/1, Sir Bernard Burrows, "Annual Report on Turkey for 1960", Britanya Büyükelçiliği, Ankara, 6 Ocak 1961.

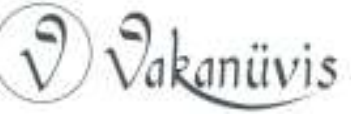


çetelerine, kesin zafere götüren doyurucu bir yol sağlamıyorsa, o zaman, kurallar değiştirilmelidir. Hükümetin, muhalefetin siyasal faaliyetlerini soruşturmak amacıyla, kadrosunun tamamını DP üyelerinin oluşturduğu bir parlamento komisyonu kurmak için meclisteki çoğunluktan yararlanarak yapmaya koyulduğu aslında buydu. Bu komisyona ülkenin siyasal yaşamında neredeyse sınırsız yetkiler verilmesiyle, bütün siyasal faaliyetleri, hatta komisyonun faaliyetleriyle ilgili parlamento tartışmalarının basında haber yapılmasını yasaklamak için bu yetkilerin hemen kullanılmasıyla belki dönüşü olmayan noktaya gelindi. ${ }^{18}$

Geçmişe bakıldığında, ülkede gerçek iktidarın kim olduğunu asla doğru tahlil edemediler gibi geliyor. Olaylar zirveye çıktığında kırsal kesim seçmenlerinin çoğunun DP'yi desteklemesinin veya hükümetin radyoyu denetlemesinin hiç bir sonuç vermediği görülüyordu. Mahkemelerin genellikle hükümetten gelen siyasal baskıyı kabul etmek istememesi, muhalefetle entelektüellerin başlıca kentlerin sokaklarında üstünlüğü sağlayabilmesi ve ordunun onları bastırmaması önemliydi. ${ }^{19}$

1960'ın başında Türkiye'nin durumunu analiz eden Burrows bu olaylı yılın birçok paradoksundan birinin bu olduğu yorumunu yaptı: Demokrat Parti hükümeti içişlerinde böyle tehlikeli ve yanlış bir yola nasıl girebiliyordu, oysa dış siyasetinde Batı́nın müttefiki olarak bu kadar azimliydi, bunun unsurlarından biri, her şeye rağmen

18 FO371/160212/RK1011/1, Sir Bernard Burrows, "Annual Report on Turkey for 1960", Britanya Büyükelçiliği, Ankara, 6 Ocak 1961. Erik J. Zürcher, Turkey: A Modern History, Londra, 1994, s. 249-252.

19 FO371/160212/RK1011/1, Sir Bernard Burrows, "Annual Report on Turkey for 1960", Britanya Büyükelçiliği, Ankara, 6 Ocak 1961.

DP 1946 'da kurulduğunda daha büyük özgürlük taahhüt ettiği için entektüellerin çoğu onu desteklemişti. Ne var ki DP hükümeti 1955-1960 yılları arasında entelektüellerin desteğini giderek kaybetti, entelektüeller neredeyse tamamıyla vazgeçtiler. Entelektüeller hükümetin üniversitelere doğrudan müdahale etmesini, basına yaptırımlarını ve DP'nin radyoyu kamu çıkarından çok propaganda için kullanmasını eleştirdiler. Öğrencilerin hükümet aleyhine gösteriyle birlikte entelektüeller pasif direnişe başladılar. Böylece CHP, entelektüeller ve basın hükümete karşı bir grup oluşturdu. Hükümet, bu tehdit karşısında muhalefetin siyasal faaliyetlerini soruşturmak için 18 Nisan 1960'da "Parlamento Komisyonu"nu kurdu. Bkz. Cem Eroğul, Demokrat Parti Tarihi ve Ideolojisi, Ankara, 1990, s. 155.

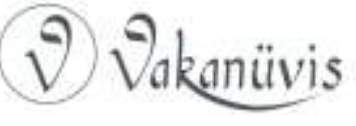


demokrasinin erdemlerine ortak inancıydı ve Kıbrıs çözümünü planlayıp kabul ettirerek dikkate değer devlet adamlığını kanıtlamıştı, bu konuda muhalifinden büyük bir siyasal bilgeydi. ${ }^{20}$

Göktepe'nin belirttiği gibi, Burrows'un analizi esasında doğruydu ama Amerika Birleşik Devletleri'nin Türkiye'nin ekonomik yardım talepleri karşısında olumsuz tutumundan ve Türkiye-Sovyet ilişkilerini de etkileyen bloklar arasındaki genel yumuşama siyasetinden de söz edilmelidir. Başka bir etken Türk siyasetçilerin Batı siyasetini körü körüne izlemekle hata ettiklerini artık anlamalarıydı. Türkiye'nin ilişkilerini kuzey komşusuyla da geliştirmeleri gerektiğini düşünüyorlardı. Sovyetler Türkiye'ye önemli miktarda yardım ve kredi de öneriyordu. Karşılıklı ziyaret mutabakatına göre, Menderes'in 1960 Temmuz'unda Moskova'yı ziyaret etmesi planlanıyordu ama 27 Mayıs 1960 darbesi nedeniyle bunu yapamadı. ${ }^{21}$

Ülkede gerilimi artıran, darbeye yol açan birçok olay vardı. Bazısı daha önce başlamış olmakla birlikte, esas itibarıyla 1960 ilkbaharında bir noktada birleştiler. DP'yi düşüşe götüren yol, CHP lideri 75 yaşındaki İnönü'nün Kayseri'yi ziyaret ettiği 3 Nisan 1960'ta başladı. Hükümet bu ziyareti önlemeye karar verdi. Bu durumda, Kayseri valisi Inönü'nün trenini durdurdu, planından vazgeçmesini söyledi ama Inönü dikkate almadı, sonunda tren onu gideceği yere götürdü. Ertesi günü vali İnönü’nün Yeşilhisar ilçesine gitmesini engellemek için silahlı kuvvetleri çağırdı. Ne var ki askerler İnönü'ye saygılarından valinin

20 FO371/160212/RK1011/1, Sir Bernard Burrows, "Annual Report on Turkey for 1960", Britanya Büyükelçiliği, Ankara, 6 Ocak 1961.

Dış siyasetin Amerikan yardımına dayanarak bir ölçüde ekonomik kalkınmayı finanse etmek, dolayısıyla, hükümete dolaylı siyasal yarar temin etmek için çok büyük avantaj sağlayacağı hesap ediliyordu. Kredinin nedeni Dışişleri Bakanı F. R. Zorlu'nun dış siyaset teknisyeni olarak dürüstlüğü ve Menderes'in özellikle Kıbrıs ve Orta Doğu'da ona verdiği geniş yetkiydi. Ne var ki gerilimin son belirtileri dış siyasette bile ortaya çıkmaya başladığında, Menderes Sovyetler gibi totaliter sistemlerde ekonomik kalkınma önlemlerini kısa zamanda uygulamanın daha kolay olduğundan birkaç defa epey gıptayla söz edildiğini duymuştu. Dahası, Krusçev'le karşılıklı ziyaretlerde bulunmakta mutabık kalmasına Türkiye'nin önceki aşırı anti-Sovyet tutumundan ihtiyatla vazgeçmesi kadar dikkati içişlerindeki krizden başka yöne çekmek için bir umut olarak da bakılabilir. Bkz. FO371/160212/RK1011/1, Sir Bernard Burrows, "Annual Report on Turkey for 1960", Britanya Büyükelçiliği, Ankara, 6 Ocak 1961.

${ }^{21}$ Göktepe, a.g.m., s. 154.

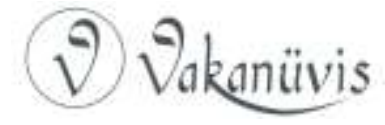


emrine uymadılar. Bir albayla iki binbaşı, anayasanın ona tanıdığı istediği yere gitme hakkını elinden almaları emrini protesto ederek istifa etti. Hemen tutuklandılar. ${ }^{22}$

Hale'in belirttiği gibi, Kayseri olayı Menderes'in muhalefete zincir vurmaya ne kadar hazır olduğunu gösterdiği gibi ihtiyacı olursa ordunun desteğine bel bağlayamayacağına da işaret ediyordu. ${ }^{23}$ Burrows da gönderisinde aynı görüşteydi: "Bunun hemen etkisi hükümetin saygınlığına ciddi bir darbe oldu. Türk silahlı kuvvetlerinin büyük kısmında Inönü’nün prestiji göz önüne alınırsa askeri birlikleri bizzat onun aleyhine kullanma girişiminde hükümetin ne düşündüğünü anlamak hâlâ zor." ${ }^{24}$ Aslında bu bir dönüm noktasıydı. Hükümete karşı orduyla muhalefet arasındaki ilişkiler eskisinden daha yakındı. Kayseri olayının ardından, 17 Nisan 1960'da İnönü evinde bir grup eski general ve amiralle görüştü, Türkiye'nin ilerleme ideallerini korumanın onlara bağlı olduğunu söyledi. ${ }^{25}$

DP'nin, CHP'nin silahlı kuvvetleri yasa ve düzene uymamaya gizlice kışkırtıp kışkırtmadığını soruşturacağını duyurmasına neden oldu bu. Dolayısıyla, 18 Nisan'da Tahkikat Komisyonu kuruldu. Siyasal faaliyetleri, basını, mitingleri soruşturmak içindi bu, Komisyon bunları hemen yasakladı. ${ }^{26}$ Dahası, başka bir yasa komisyona çok acımasızca denetleme ve tutuklama hakkı veriyordu. İnönü karşı çıktı: "Böyle giderseniz sizi ben bile kurtaramam." ${ }^{27}$ Daha önce, "Şartlar tamam olduğunda milletler için ihtilal meşru bir haktır" dediği belirtiliyordu. ${ }^{28}$

Bundan sonra İnönü'ye bu konuşmaları nedeniyle Meclis'in sonraki on iki oturumuna katılmama cezası verildi. Bu nedenle, Meclis parlamentoda problemleri çözme işlevini kaybetti. Siyasal gerilim artarken üniversite öğrencileri hükümetin siyasetini ülke çapında

\footnotetext{
22 Göktepe, a.g.m., s. 156

${ }^{23}$ William Hale, Turkish Politics and the Military, Londra, 1994, s. 105.

24 FO371/153032/RK1015/10, Burrows' tan Britanya Dışişleri Bakanlığı'na (Selweyn Lloyd), Ankara, 22 Nisan 1960.

${ }^{25}$ Hale, a.g.e., s. 106.

${ }^{26}$ Walter F. Weiker, The Turkish Revolution, 1960-1961: Aspects of Military Politics, Washington D.C., 1963, s. 15.

${ }^{27}$ Hale, a.g.e., s. 106

28 FO371/153032/RK1015/11, Burrows'tan Britanya Dışişleri Bakanlığı'na, 29 Nisan 1960.
}

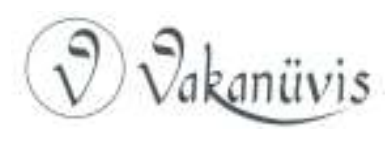


protesto etmeye başladılar. 28 Nisan 1960'da İstanbul Üniversitesi öğrencilerinin gösterileri sırasında ordu ve polis öğrencileri bastırdı. íki öğrenci öldürüldü, birçoğu yaralandı. Basın sansürü nedeniyle olayların ayrıntıları halka duyurulmadı. Yine de altmış veya daha çok öğrencinin öldürüldüğü söylentileri hemen yayıldı. Protestolar artarken hükümet 28 Nisan 1960 'da İstanbul ve Ankara'da sokağa çıkma yasağıyla birlikte sıkıyönetim ilan etti. ${ }^{29}$ Ertesi günü Ankara'da Siyasal Bilgiler Fakültesi öğrencilerinin düzenledikleri mitingde gösteri yapan kalabalıklar vardı. Göstericiler Menderes'i istifaya çağırıyorlardı. ${ }^{30}$

Başka bir önemli olay 5 Mayıs'ta Ankara'da meydana geldi. Menderes, gösteri düzenlenen Kızılay Meydanı'ndan geçiyordu. Otomobilini durdurup dışarı çıktığında öğrenciler onu tartakladılar, kaza eseri kalabalıkta sıkışıp kalmış bir gazetecinin otomobiline güçlükle bindi. Ofisine dönüp Cumhurbaşkanıyla görüştükten sonra Cumhurbaşkanı Bayar iç̧işleri Bakanına göstericilere ateş açma emri verdi. Emniyet görevlileri yine de ateş etmedi. Fakat bu emir Bayar'ın Menderes'in üzerinde nüfuzunu nasıl artırdığını gösterdiğinden önemliydi. ${ }^{31}$

Darbeden önce son önemli olay Hindistan Başbakanı Nehru'nun 2022 Mayıs'ta Ankara'yı ziyareti sırasında meydana geldi. 21 Mayıs'ta 1000 kadar subayla Kara Harp Akademisi öğrencisi birçok subayın keyfi tutuklanmasını protesto etmek için Çankaya'nın dışındaki başbakanlık konutuna toplu yürüyüş düzenledi. Olaya hükümetin gözünü korkutma girişimi olarak bakıldı. ${ }^{32}$

Menderes, istifa etmesi için dört bir yandan büyük baskı yapılsa da boyun eğmedi. İzmir'i ziyaret ettiğinde neredeyse 200 bin kişilik coşkulu büyük bir kalabalık onu karşıladı, sempatisini ve desteğini gösterdi, Menderes'in kalma kararını etkiledi. Sonra, 25 Mayıs'ta

29 Hale, a.g.e., s. 106. FO371/153032/RK1015/11, Burrows'tan Britanya Dışişleri Bakanlığı'na, 29 Nisan 1960.

30 Hale, a.g.e., s. 106. FO371/153032/RK1015/11, Burrows'tan Britanya Dışişleri Bakanlığı'na, 29 Nisan 1960.

31 Hale, a.g.e., s. 106. FO371/153032/RK1015/11, Burrows'tan Britanya Dışişleri Bakanlığı'na, 29 Nisan 1960.

32 Hale, a.g.e., s. 106. FO371/153032/RK1015/11, Burrows'tan Britanya Dışişleri Bakanlı̆̆ı'na, 29 Nisan 1960.

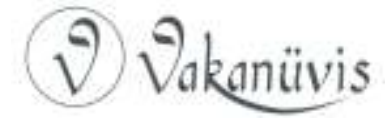


Eskişehir'e gitti, mitingde konuşma yaptı. Tahkikat Komisyonu'nu feshedeceklerini ve erken seçim tarihini ilan edeceklerini vurguladı. Hoparlörlerin kablosu kesildiği için kalabalık onun sözlerini işitmedi. 27 Mayıs 1960'da hâlâ Eskişehir'deyken sekreteri sabah 04:00'te onu uyandırarak askeri darbe haberini verdi. ${ }^{33}$

Demokrat Parti hükümetinin Türkiye'de siyasal istikrarı sağlamaya devam edip etmeyeceği Britanya hükümeti için şimdi önemli bir soruydu. Britanya'nın Ankara Büyükelçiliği'nden gelen raporlar Türkiye'de bazı iç problemleri belgelemekle birlikte durumun hükümetin denetiminde olduğu bilgisini veriyordu. Sonuçta, hükümete karşı askeri harekât ihtimali pek mümkün gibi görünmemişti. Yine de, 1960 Nisan'ında görüşleri önemli ölçüde değişti. Burrows 22 Nisan 1960 tarihli gönderisinde potansiyel bir "devrim durumu" bulunduğunu belirtti. Menderes Anayasayı askıya alma ve kararnameyle hükümeti devam ettirme kararı verdiği takdirde, Anayasayı korumak için planlanmış bir askeri müdahaleyi öngörebildiği koşulları vurguladı. ${ }^{34}$ Şunu belirtti:

"Komisyon ülkede bütün siyasal faaliyetleri ve mitingleri çoktan yasakladı. Gelecek gelişmeler belli değil. Potansiyel bir devrim durumu var. Fakat İnönü ve partisi meseleleri uç noktaya götürmeyi şimdilik istemiyor gibi görünüyor. Aslında 18 Nisan'da Meclis görüşmesinin ikinci konuşmasında böyle bir eğilime özellikle karşı çıktı. Hükümetin de, yurt içinde birliğin olmaması, orduya güvensizliği ve yakın gelecekte, önümüzdeki ayın başında i̇stanbul'da NATO Bakanlar Toplantısı beklentisiyle aşırı uçlara gitmesi önlenebilir." ${ }^{\text {35 }}$

Britanya Dışişleri Bakanı 2-4 Mayıs 1960'da İstanbul'da NATO bakanlar toplantısına katılacağından, Türkiye'nin iç güvenliği Britanya Dışişleri Bakanlı̆̆ı'nı ilgilendiriyordu şimdi. Britanya Dışişleri Bakanlığı bazı üst düzey yetkililerin hükümetin muhalefete karşı aldığı önlemlerden hoşnutsuzluğunu daha önce gösterdiğini aklında

33 Mehmet Ali Birand, Can Dündar, Bülent Çaplı, Demirkırat: Bir Demokrasinin Doğuşu, ìstanbul, 1991, s. 135.

${ }^{34}$ FO371/153032/RK1015/10, Burrows'tan (Selweyn Lloyd), Ankara, 22 Nisan 1960. FO371/153032/RK1015/8, The note written by G. M. Galbraith'in (Güney Dairesi) yazdığı not, 20 Nisan 1960.

35 FO371/153032/RK1015/10, Burrows'tan Britanya Dışişleri Bakanlığı'na (Selweyn Lloyd), Ankara, 22 Nisan 1960.

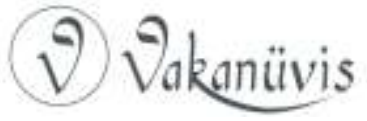


tutuyordu. Burrows telgrafında erken bir şiddet eylemini göz önüne alıyordu ama bu ihtimali önemsemiyor gibi görünüyordu. Güney Dairesi Başkan Yardımcısı E. J. Barnes şu raporu yazdı: "Muhtemel bir güvenlik tehdidinde Burrows'un bizi zamanında uyaracağına güvenebileceğimizden eminim." ${ }^{36}$

Türkiye siyasetinde aydın kesim dışında asker de başka bir önemli etkendi. Askerin motifleri karışıktı. Birçok subay, İnönü'ye Atatürk'ün yoldaşı olduğu için bağlıydı, CHP'ye her zaman böyle bağlı değildi; diğerleri ordunun siyasal amaçlar için kullanılmasına içerliyordu; diğerlerinin de Türkiye'nin siyasal geleceğiyle ilgili daha derin, daha radikal görüşleri vardı, bütün siyasetçilerin kötü olduklarına ve hem Türkiye'yi şimdiki siyasal krizden kurtarmak hem de yeni ve bazı durumda, seçilmiş hiçbir hükümetin üstlenecek kadar kendini güçlü hissetmeyeceği popülist olmayan, uzun vadeli reformlar yaparak Atatürk'ün işini tamamlamak için en azından şimdilik hükümet sisteminde kapsamlı bir değişiklik gerektiğine inanıyorlardı. Komplo maksadıyla bir araya gelen bu farklı unsurlar dikkat çekecek derecede etkin ve başarılı bir devrim yaptı. Ne var ki daha sonra ayrıldılar, son grubun önde gelen temsilcilerinden Albay Türkeş ve arkadaşları geçici olarak sahnenin dışına sürüldüler. ${ }^{37}$

1960 darbesini planlayıp gerçekleştiren grup, iki genç subayın, Dündar Seyhan'la Faruk Güventürk'ün radikal düşünceli subaylardan bir hücre oluşturmaya başladığı 1955'te başlamış gibi görünmektedir. Kendilerine Devrim Komitesi veya sadece Komite diyorlardı, faaliyetlerini 1957 ve 1958 yılları boyunca genişlettiler. Ankara grubunu 1956 yılı sonunda Talat Aydemir, Osman Köksal, Sezai Okan ve Adnan Çelikoğlu kurdu, 1958'de İstanbul komitesi ağlarını birleştirmeye karar verdi. íktidarı devralma planlarının başarısı için iki şey önemliydi. Biri, üyelerini komuta konumlarında görevlendirmekti,

36 FO371/153032/RK1015/8, E. J. Barnes'ın notu (Güney Dairesi), 20 Nisan 1960. Menderes Ankara'da kalmak ve gelişmelerle temasını sürdürmek için toplantıda yapacağı konuşmayı iptal etti. NATO ülkelerinin dışş̧leri bakanlarına durumun ciddiliğini bu açıkça gösterdi.

37 FO371/160212/RK1011/1, Sir Bernard Burrows, "Annual Report on Turkey for 1960", Britanya Büyükelçiliği, Ankara, 6 Ocak 1961. Zürcher, a.g.e., s. 254-256. Ayrıca bkz. Ümit Özdağ, Menderes Döneminde Ordu-Siyaset ilişkileri ve 27 Mayıs ihtilali, İstanbul, 1997.

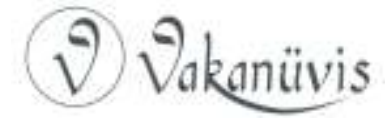


iktidarı devralmak için bu gerekliydi, ikincisi silahlı kuvvetlerin geri kalanının desteğini kazanmak için hareketlerinin başına geçecek üst rütbeli bir subay bulmaktı. Sonunda, ikisini de başardılar. Birkaç başarısız girişimden sonra baş figür olarak ihtiyaç duydukları üst rütbeli subayı buldular; Savunma Bakanı'na askerin hükümet politikalarından hoşnutsuzluğunu ifade eden bir memorandum yazdığı için 3 Mayıs 1960 'da sürekli izne çıkarılan eski Kara Kuvvetleri Komutanı General Cemal Gürsel. ${ }^{38}$ Hükümetin istifasını isterken hoşnutsuz askerin temsilciliğini yapıyordu. ${ }^{39}$

Savunma Bakanı Ethem Menderes mektubu Başbakana götürdü. Menderes memorandumu görünce istifaya karar verdi. Ne var ki Cumhurbaşkanı Celal Bayar istifasını kabul etmedi, destek mesajı gönderdi. Cumhurbaşkanının tutumu bildirildiğinde Menderes fikrini değiştirdi. Görünen o ki kendisinin ve hükümetinin hâlâ gösterileri bastıracak, ülkenin iç problemlerini çözecek dirayeti bulunduğunu umuyordu. Genel kamu desteğinin arkasında olduğunu düşünüyordu. Gerçi Savunma Bakanının da, Başbakanın da Cumhurbaşkanını memorandum konusunda bilgilendirmemesi önemli bir noktaydı ${ }^{40}$

Memorandum çok açıktı ve askeri darbeden önce hükümete son uyarıydı. Hükümet önemini kavramış gibi görünmüyordu. Genelkurmay Başkanı General Rüştü Erdelhun hükümete sadıktı ve hükümete herhangi bir müdahaleye karşı çıkacağı biliniyordu. Dahası, yirmi General Başbakanı ziyaret etti ve hükümete itaat edeceklerini doğruladı, bu durumda hükümet Türk ordusunun hiyerarşik disiplinine

38 Sevecen bir baba figürü olan General Gürsel'i bütün Silahlı Kuvvetler iyi tanıyor ve beğeniyordu. MBK başkanı olmayı kabul etti ama örgütün ayrıntılarına girmedi. Aslında, darbeyi, komutanlarını göreli geç bir evrede hazırlıklara dâhil eden bir grup orta ve ast rütbeli subay başlattı. George Harris'in dediği gibi, "Türkiye'de askerlik mesleğinin güçlü hiyerarşi eğiliminden yararlanmak için astların işe aldıkları yüksek rütbeli subayların ön cephede bulunduğu, öz[ünde] [bir] albaylar darbesi olmuştu bu." 27 Mayıs 1960'da darbe yapıldığında General Gürsel Devrim Komitesi'nin başkanı olarak hava kuvvetlerinin uçağıyla İzmir'den Ankara'ya getirildi. Bkz. George Harris, "The Causes of the 1960 Revolution in Turkey", Middle East Journal (MEJ), Cilt: 24, (Sonbahar 1970), s. 438-454.

${ }^{39}$ Hale, a.g.e., s. 100 . Zürcher, a.g.e., s. 253-254.

${ }^{40}$ Birand, Dündar, Çaplı, a.g.e., s. 168. Göktepe, a.g.m., s. 146.

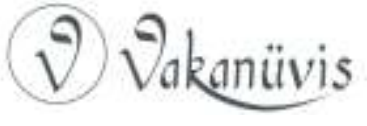


güvenmeye karar verdi. Orta rütbeli subaylarla astlardan hükümete karşı bir komplo beklemiyorlardı. ${ }^{41}$

Burrows 3 Temmuz 1960'da Londra'ya durumu doğru tahlil ettiği gizli bir gönderi yolladı. Orta ve alt rütbeli subayların DP hükümetini uzun zamandır beğenmediklerini, birçoğunun eğitimli sınıflarla ilişkisi bulunduğunu ve muhalefete sempati beslediğini belirti. illaveten, maaş ve hizmet koşulları çok kötüydü. Üst rütbeli subaylar astların bu duygularının kuşkusuz farkındaydılar. İnönü’nün partisindense şahsına büyük saygıları vardı. Hükümetin öğrenci gösterilerini bastırmak için orduyu kullanmasını uygun bulmuyorlardı. "Orduyu siyasetin uzağında tutmak ve halkla yakın bağlarını sürdürmek" istiyorlardı. ${ }^{42}$

27 Mayıs 1960 'da Türk Silahlı Kuvvetleri Demokrat Parti'yi devirdi ve eski rejimin bütün liderlerini tutukladı. Eski Kara Kuvvetleri Komutanı General Cemal Gürsel'in başkanlığında Milli Birlik Komitesi $(\mathrm{MBK})^{43}$ yönetimi üstlendi. Ertesi günü General Gürsel'in Devlet Başkanı ve Başbakan olduğu yeni hükümet kuruldu. Burrows, ordu, hükümetin gösterileri bastırma emirlerine karşı "pasif direniş" in Türkiye'nin kendini içinde bulduğu krizi çözmeye yetmediğini, durumu

41 Göktepe, a.g.m., s. 147.

42 FO371/153034/RK1015/33, Burrows'tan Britanya Dışişleri Bakanlığı'na, 3 Haziran 1960.

43 General Cemal Gürsel ve silahlı kuvvetlerin her sınıfını temsil eden (gerçi ağırlıklı olarak karacı, ancak üçü hava kuvvetlerinden, ikisi deniz kuvvetlerinden) 37 subay Milli Birlik Komitesi'nde örgütlendi. MBK büyük ölçüde orta rütbeli subaylardan meydana geliyordu. Rütbeleri şöyleydi: beş general, yedi albay, beş yarbay, on üç binbaşı ve sekiz yüzbaşı. MBK üyelerinin büyük çoğunun yaşları 35-46 arasındaydı. MBK silahlı kuvvetlerde hepsi iktidara aç, farklı fraksiyonların koalisyonuydu. Cunta kalabalıktı ve yönetilmesi zordu, çünkü farklı birçok grup temsil edilme iddiasındaydı. MBK ülkeyi yönetmek için 12 Haziran 1960'da çıkarılan geçici yasayla yasal yetkiyi üstlendi. Bu belge yeni anayasayla meclis seçilinceye kadar Türk milleti adına egemenliğini yürütmesini sağladı. Cuntanın yasama gücü, MBK'nın de başkanı olan Devlet Başkanının görevlendirdiği kabine vasıtasıylaydı. Komite bakanları görevden alabilirdi ama onları sadece Devlet Başkanı atayabilirdi. Sadece yargı sistemi cuntadan bağımsız işlev yaptı, yürütme gücü sivil Bakanlar Konseyinin elinde kaldı, yine de cuntanın yakın takibindeydi. Bilinen adıyla "Teknokratlar Kabinesi" 18 üyeden oluşuyordu (üç subay ve 15 sivil), MBK'nın atadığı ve denetlediği bir yürütme organıydı sadece. Dolayısıyla, önemli bütün siyasal kararları MBK veriyordu. Bkz. FO371/153035/RK1015/39, Burrows'tan Güney Dairesi'ne, 17 Haziran 1960. Ahmad, a.g.e., s. 126-27. Zürcher, a.g.e., s. 254.

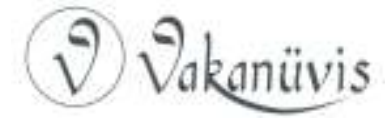


değiştirmek için bunun yerine "kesin eyleme" geçmeleri gerektiğini sonunda anladığı için devrim yapıldığını belirtti. ${ }^{44}$ Burrows, Menderes rejiminin düşmesinin arkasındaki nedenleri şöyle belirtti:

Menderes hükümeti ne pahasına olursa olsun iktidarı elinde tutmaya kalkışarak, muhalefetin aleyhine parlamentoda soruşturma komisyonu kurulmasına yol açarak kendi düşüşüne katkıda bulundu. Hükümet ülkede iktidarın durumunu yanlış değerlendirdi ve kendi icraatıyla orduyu müdahalede bulunmaya sevk eden bir siyasal kriz yarattı. Demokrat Parti hükümeti tedbirsiz iç siyasetine rağmen Batı ittifakının sadık bir üyesi olarak kaldı. Demokrat Parti kentli entelektüellerle köylü çoğunluk arasındaki uçurumu kapatmaya bir ölçüde çalıştı. Önemini küçümsediği entelektüellerin desteğini kaybedince sonunda özellikle köylülerin desteğine güvendi. ${ }^{45}$

İngilizlerin görüşüne göre, Demokratik Parti'nin yıkılması daha "trajikti", çünkü Türkiye'nin "iki milleti”, okumuşla okumamış, kentte yaşayanlarla köylüler arasında teması sağlamak için gösterilen yeni çabalardan birini temsil ediyordu. 1946'dan önce hemen her siyasal icraat üst sınıflar arasında yürütülüyordu, Atatürk bile yirminci yüzyıla atlarken köylü nüfusu yanına almayı başaramamıştı. Onun dine yönelik tutumunu beğenmeyen çok kişi vardı, eğitim eski âdetleri kökünden sökecek kadar hızla veya derinlere yayılmamıştı. İktidarın merkezini Anadolu'nun ilkel erdemlerine geri getirmeye niyetlenen Ankara ikinci İstanbul haline gelmişti, Ankara'yla ancak birkaç mil ötesindeki köyler arasında büyük görüş farkı vardı. Burrows saygın bir maliyecinin kendisine, "Gençliğinde ama Atatürk devriminden sonra vergi memuru olarak bir köye klymet takdiri yapmaya gittiğinde kendisini yurttaştan çok işgal kuvveti ajanı gibi hissettiğini ve kendisine böyle davranıldığını" anlattığını aktarır. ${ }^{46}$

44 FO371/160212/RK1011/1, Sir Bernard Burrows, "Annual Report on Turkey for 1960", Britanya Büyükelçiliği, Ankara, 6 Ocak 1961.

45 FO371/160212/RK1011/1, Sir Bernard Burrows, "Annual Report on Turkey for 1960", Britanya Büyükelçiliği, Ankara, 6 Ocak 1961.

46 FO371/160212/RK1011/1, Sir Bernard Burrows, "Annual Report on Turkey for 1960", Britanya Büyükelçiliği, Ankara, 6 Ocak 1961.

1946 'da iki partili sistemin kurulmasıyla siyasetçiler için kırsaldaki kitlelerle ilgilenmek ilk kez değerli oldu. Her erkeğin ve kadının, ne kadar eğitimsiz olursa olsun bir oyu vardı. Ülkedeki muhalif hareketlerin hemen hepsi gibi, iktidara gelmeden önce DP'de

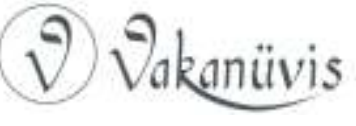


Darbeden sonra Britanya hükümeti kendini ikilem içinde buldu. Bir yandan, antidemokratik müdahale demokrasi sürecine ara vermişti. Britanya demokrasiye bağ|ıı̆ı nedeniyle, ortaya çıkan bu tür bir rejimi destekleyemezdi. Öte yandan, Britanya'nın ekonomik, stratejik ve askeri çıkarları yeni askeri rejimle ilişkilerini devam ettirmesine neden oluyordu. Bu durumda Britanya hükümetinin ikilemi çözmek için Amerika Birleşik Devletleri'ne danışması uzun sürmedi. ${ }^{47}$

Amerika'nın Ankara Büyükelçisi Fletcher Warren hükümetini yeterince bilgilendirmediği için Menderes rejiminin yıkılması Washington için tam bir sürpriz oldu. Büyükelçi raporlarında Menderes'in çok güçlü olduğundan, ordunun onu desteklediğinden ve Genelkurmay Başkanının ona itaat ettiğinden söz etmişti. ${ }^{48}$ Öte yandan, Britanya'nın Ankara Büyükelçiliği Türkiye'nin iç durumuyla ilgili düzenli bilgi gönderdiği için Britanya hükümeti Türkiye'deki darbeye ABD kadar şaşırmadı. Burrows Türkiye'nin iç manzarasının belirgin özelliğinin 1955-1960 yılları arasındaki sakin zamanla birlikte dönem dönem şiddet ve öfke patlamaları olduğunu ayrıntılı yazdığı gönderisinde Menderes hükümetinin muhalefetle uğraşmasında, özellikle de muhalefeti ve basını bastırma eğiliminde yaptığı yanlışları

de çoğunluğu entelektüeller oluşturuyordu. Köylülerle çalışmayı sürdürmelerinin başlıca nedeni, CHP köylüler için hiç zahmete girmemişti ve köylüleri doğdukları yerde tutmak için aslında polis ve jandarma şiddetinden yararlanmıştı. DP 1950'de iktidara geldiğinde köylü destekçilerine yollar yaparak, su sağlayarak, elektrik vererek ve İslam'ın yeniden canlanmasına izin vererek karşılığını ödedi. Özellikle Doğu'da bazı aşiret reislerine ve büyük toprak sahiplerine eski hükümetlerin azaltmaya gayret ettikleri fiili feodal otoritelerine devam etme imkânı da verdi. Bunların çoğu oy alma politikası gibi gelse de, bazı Demokratlar hükümetle hükümet edilen bu çoğunluk arasındaki uçurumu kapatmanın önemini anladı. Yine de genelde iktidarı kötüye kullanmanın yanı sıra köylülerin peşine düşmekte kullanılan yöntem partinin entelektüellerin desteğini kaybetmesine katkıda bulundu, entelektüeller 1955-1960'da partiyi neredeyse tamamıyla terk ettiler. DP bunu çok önemsemedi, çünkü entelektüellerin birkaç oyu etkileyebildiklerini düşünüyorlardı. Ancak yanılıyorlardı, çünkü bir tarım devletinde bile siyaset hâlâ kentlerde yapılıyordu ve okuma yazma düzeyinin düşük olduğu bir ülkede ordunun subay sınıfı kendine entelektüel kesimin bir sınıfı gözüyle bakıyordu, oysa köylü zümrelerde uyum veya itici güç yoktu. Bkz. FO371/160212/RK1011/1, Sir Bernard Burrows, "Annual Report on Turkey for 1960", Britanya Büyükelçiliği, Ankara, 6 Ocak 1961.

${ }^{47}$ Weiker, a.g.e., s. 160.

${ }^{48}$ Weiker, a.g.e., s. 160.

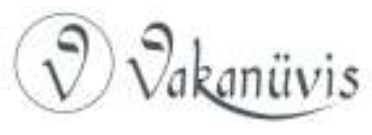


belirtti. DP'nin bu düşünce eğilimine, Türkiye'nin Batı'da uygulanan demokrasi biçimlerine uygun olmadığı, bunları benimsemeye çalışırsa bireyselliğini kaybedeceği kanısıyla kimi zaman mantıklı bir açıklama getirildi. Bu felsefenin Başbakan Menderes'e çekici geldiğine inanmak için bir neden vardır, gerçi eskiden bunu uygulamaya koymak için gereken önlemleri almaktan çekinmişti. ${ }^{49}$

Burrows'un Amerika'nın Ankara Büyükelçisiyle yakın ilişkileri vardı. Fletcher Warren darbeden bir gün sonra General Gürsel'le gayrı resmi bir görüşme yaptı. Türkiye'nin yeni Dışişleri Bakanı Selim Sarper ${ }^{50}$ Burrows'a, General Gürsel'le görüşmek isterse onun da memnun olacağını söyledi ama Britanya Büyükelçisini resmi olarak davet etmeyi doğru bulmamıştı. Bu koşullarda Burrows yeni hükümetin tanınması bitmeden önce General Gürsel'le görüşüp görüşmeyeceği konusunda Britanya Dışişleri Bakanlığı'ndan acil talimat istedi. Dışişleri Bakanlığı bu yetkiyi verdi, Türkiye'nin yeni rejimiyle erkenden temas kurmanın önemi ve Amerika Büyükelçisinin General Gürsel'i çoktan ziyaret etmiş olması konusunda Büyükelçinin görüşüne katıldı. Britanya Büyükelçisi uygun olan en kısa sürede General Gürsel'le özel görüşme yapmaya çalışmalıydı. ${ }^{51}$

ABD’nin yeni Türk hükümetine yönelik tutumu konusunda Britanya Dışişleri Bakanlığı'nın aldığı istihbarata göre, Amerikan hükümeti, Türkiye'nin Washington Büyükelçisinin 28 Mayıs'ta onlarla irtibat kurmasına, yeni Türkiye hükümetini hemen tanımalarını haklı gösterecek yeterli bir kanıt gözüyle bakıyordu. Bu durumda, Fletcher Warren Washington'dan yeni Türkiye hükümetiyle olağan işlerini 30 Mayıs'ta yeniden yürütmeye başlama talimatı almıştı. $O$ tarihte Britanya hükümeti yeni Türk hükümetini ABD'yle aynı zamanda tanımayı çok istiyordu, geride kalmış görünümü vermek istemiyordu.

49 FO371/153032/RK1015/10, Burrows'tan Britanya Dışişleri Bakanlığı'na (Selweyn Lloyd), Ankara, 22 Nisan 1960.

50 Selim Sarper darbeden hemen sonra askeri rejim tarafından dışişleri bakanı olarak atanmadan önce Türk Dışişleri Bakanlığı'nda müsteşardı. DP hükümeti döneminde önde gelen diplomatlardan biriydi. Uluslararası camia ve dış ilişkiler konusunda çok deneyimliydi. İdam cezalarına şahsen karşıydı, uluslararası arenada bunların Türkiye'nin adını olumsuz etkileyeceğinin farkındaydı.

51 FO371/153046/RK1051/3, Burrows'tan Britanya Dışişleri Bakanlığı'na, 29 Mayıs 1960.

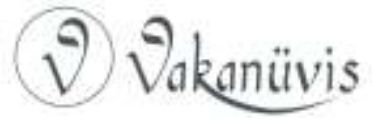


Nitekim Britanya hükümeti de yeni Türk hükümetini 30 Mayıs'ta tanıdı. ${ }^{52}$

Britanya Dışişleri Bakanlığı Burrows'a General Gürsel'le görüşmesi konusunda geniş talimatlar verdi. Britanya'nın Türkiye'nin içişlerine müdahale etme niyeti kuşkusuz bulunmadığından ve bunu yapmasının çok uygunsuz olacağını anladığından söz ediliyordu. Yine de Bağdat Paktı' ${ }^{\prime} \mathbf{n}^{53}$ ilk günlerinde Süveyş meselesinden, Irak devriminden ve Kıbrıs krizinden endişe edilirken, daha sonra Zorlu'nun desteklediği Menderes Britanya'yla ittifakını desteklemek için gerçek dost, müttefik ve Türk milletinin değerli sözcüsü görevini yapıyordu. Dolayısıyla, Britanya hükümeti bu siyasal sıkıntı döneminde bunun kendileri lehine hatırlanacağını ve yeni Türk hükümetinin Türkiye'nin eski liderlerine davranışını etkileyeceğini düşünüyordu. Bunun resmi bir diplomatik girişim olmamasını, eski dostlarının ve meslektaşlarının Türkiye'nin içişlerini idare tarzlarını asla görmezden gelmeden, onların kaderlerine gösterdikleri usturuplu bir ilginin belirtisi olmasını istediklerinden de söz ediyorlardı. ${ }^{54}$

52 FO371/153046/RK1015/2, Britanya Dışişleri Bakanlığı'ndan Washington'a, 29 Mayıs 1960. FO371/153046/RK1051/3(B), Burrows'tan Britanya Dışişleri Bakanlığı'na, 29 May 1960. Birleşik Krallık'ta Majestelerinin Hükümeti Türk hükümetinin iki ülke arasında var olan mutlu dostluk ve ittifak ilişkilerini sürdürme arzusunu tamamıyla paylaşmakta ve karşılıkta bulunmaktadır. Majestelerinin Büyükelçiliği Dışişleri Bakanlığına en derin saygılarının güvencesini tekrarlamak için bu fırsatı değerlendirmektedir. Bkz. FO371/153046/RK1051/3, Britanya Dışişleri Bakanlığı'ndan Burrows'a, 29 Mayıs 1960. FO371/153046/RK1051/3, Britanya Dışişleri Bakanlığı'ndan Ankara'ya, 30 Mayıs 1960.

İngiliz Milletler Topluluğu ülkeleri de İngiliz Milletler Topluluğu İlişkiler Dairesi aracılığıyla 30 Mayıs tarihli bir telgrafla durumdan haberdar edildi. Britanya hükümeti müttefikleri NATO ve CENTO'ya önceden danışmadan yeni Türk hükümetini tanırken Britanya Dışişleri Bakanlığı Burrows'a, Kıbrıs müzakereleri nedeniyle özel bir konumda bulunduklarını şahsi bazda belirtmesi için talimatlar gönderdi. Bu konuda en az gecikmeyle iş yapabilmeleri önemliydi. Bkz. FO371/153046/RK1051/3, Britanya Dışişleri Bakanlığı'ndan Burrows'a, 29 Mayıs 1960. FO371/153046/RK1051/3, Britanya Dışişleri Bakanlığı'ndan Ankara'ya, 30 Mayıs 1960.

53 Bağdat Paktı konusunda daha geniş bilgi için bkz. Behçet Kemal Yeşilbursa, The Baghdad Pact and Anglo-American Defence Policies in the Middle East, 1950-1959, London, 2013.

${ }^{54}$ FO371/153046/RK1015/29, Britanya Dışişleri Bakanlığı'ndan Ankara'ya, 29 Mayıs 1960. 
Burrows, gönderisine göre, 31 Mayıs'ta General Gürsel'le görüşmesinde hükümetinin yeni Türk hükümetine yönelik tutumunu açıkladı. Başka bir ülkenin iç durumu hakkında yorum yapmanın kendileri için çok yanlış olacağını ama Türkiye'nin dost ve müttefik olduğunu, Türkiye zor durumda kaldığında haliyle üzüldüklerini söyledi. Türkiye'yi sağlıklı ve güçlü görmek istiyorlardı. Sonra, Türkiye'yle bağlantı noktalarını özetledi: NATO, CENTO, Kıbrıs, kültür etkinlikleri, Türkiye'nin ekonomik kalkınmasına katkılar, silahlı kuvvetlere donanım sağlama yardımı. Bunların hepsi Türkiye'yle paylaştıkları, dünya problemlerine ortak bakış açısının yansımasıydı. Burrows başka bir gönderide, 21 Haziran 1960' da Dışişleri Bakanı Sarper'le görüştüğünde iç durum vb. konusunda yorum yapmanın kendisi için yersiz olduğuna dair her zamanki görüşlerini de kuşkusuz belirtti. ${ }^{55}$

Burrows yeni hükümetin açıklamasından, dışişleri siyasetinin temelde değişmediğini öğrenmekten özellikle memnun olduğunu vurguladı. General Gürsel çok sayıda bağlantı noktalarından ve ortak çıkarlarından takdirde söz etti, ilişkilerinin daha da yakınlaşmasını, asla gölge düşmemesini arzu ettiğini açıkladı. Aynı zamanda eski siyasetçilerden de söz ettiler. Burrows onların sağlığı ve güvenliği konusunda teminata intiyacı olduğunu söyledi, Britanya Dışişleri Bakanı'nın, eski bakanların kaderiyle şahsen ilgilendiğini ekledi. General Gürsel Britanyalı yetkililerin bu kadar yakın ilişkide bulundukları insanlar için insani duygular beslemelerinin çok doğal olduğunu, onların bu konudaki duygularını çok takdir ettiğini söyledi. Eski bakanlara şahsi düşmanlığı olmadığını vurgulamak istedi. Belirli şahısların aleyhine davranmak istediği için değil, bunu kendi görevi olarak gördüğü için böyle davrandığını söyledi. Burrows daha sonra Britanya'nın, eski hükümet üyeleriyle ilgili ricasını saldırgan olmayan bir tarzda Türk tarafına tekrarladı. ${ }^{56}$

55 FO371/153046/RK1051/5(A), Burrows'tan Britanya Dışişleri Bakanlığı'na, 30 Mayıs 1960. FO371/153046/RK1015/40, Burrows'tan Britanya Dışişleri Bakanlığı'na (A. D. M. Ross), 21 Haziran 1960. FO371/153035/RK1051/x, Britanya Dışişleri Bakanlığı'ndan (Ross) Burrows'a, 29 Haziran 1960.

56 FO371/153046/RK1051/5(A), Burrows'tan Britanya Dışişleri Bakanlığı'na, 30 Mayıs 1960. FO371/153046/RK1015/40, Burrows'tan Britanya Dışişleri Bakanlığı'na (A. D. M. Ross), 21 Haziran 1960. FO371/153035/RK1051/x, Britanya Dışişleri Bakanlığı'ndan (Ross) Burrows'a, 29 Haziran 1960.

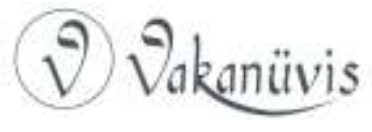


Britanya Devlet Müsteşarı Sir F. H. Müller Sarper'e Türkiye'nin içişleri konusunda yorum yapmanın kendisine uymadığından söz ettiği bir dostluk mesajı gönderdi. Yine de, eski bir dostunun ve güvenilir bir meslektaşının yeni hükümette Dışişleri Bakanlığı makamında bulunmasından memnundu. 1951'de BM'de ilk tanıştıklarından beri kendisine derin saygı ve sıcak bir dostluk duyduğundan söz etti. Sarper'in selefleriyle girdiği aynı yakın işbirliğine onunla da girmeyi çok isteyerek en içten iyi dileklerini gönderdi. Bu mesajı ne zaman ve hangi koşullarda vereceğinin inisiyatifini Burrows'a bıraktı. Miller Burrows'a yeni hükümetin yönetimi sıkıca eline aldığını hissederse kendi mesajının Sarper'in alacağı ilk mesajlardan biri olmasını istediğini de bildirdi. ${ }^{57}$

Burrows, Türk Dışişleri Bakanı olarak Sarper'le ilk kez 31 Mayıs'ta görüştü. Sarper Burrows'a yeni hükümetin programını ve dışş̧leri siyasetinin yönelimini, General Gürsel dâhil, askeri otoritelerin genel maksatlarını açıkladı. En sonunda Sarper, Burrows'a söylediği kısmın "yeni hükümetin sırlarını" açıkladığını belirtti. Burrows Britanya Dışişleri Bakanlığı'na, Türkiye'de kamuya açıklanıncaya kadar, bu konuda hiçbir öneriyi ima etmemesini tavsiye etti. ${ }^{58}$ Göktepe'nin işaret ettiği gibi, Britanya hükümetinin Türkiye'nin içişlerine müdahale ettiği görüntüsünden kaçınmak istediği ve darbeye Türkiye'nin içişi dedikleri bu gönderiden anlaşılabilir. Yine de eski hükümet üyeleriyle yakın ilişkilerini askeri hükümete hatırlatıyorlardı. Eski Başbakan Menderes'le eski Dışişleri Bakanı Zorlu’nun İngiliz mevkidaşlarıyla yakın ilişkileriyle açıklanıyordu bu..$^{59}$

Britanya Dışişleri Bakanlığı 1960 Haziran'ında Burrows'a Türkiye'nin iç ve dış ilişkileriyle ilgili bir mesaj gönderdi. Mesajda Sarper'le sohbet etmekten kaçınmaması, Türkiye'nin iç durumundaki muhtemel bir gelişme Britanya hükümetini haliyle ilgilendirdiğinden, hükümet için bunun gerçekten değerli olduğu belirtiliyordu. Öte yandan, Devlet Müsteşarı Daimi Yardımcısı A. D. M. Ross, "her şeyi oy sandığının

57 FO371/153054/RK1051/4, Britanya Dışişleri Bakanlığı'ndan Ankara'ya, 28 Mayıs 1960.

58 FO371/153046/RK1051/8, Burrows'tan Britanya Dışişleri Bakanlığı'na, 31 Mayıs 1960.

59 Göktepe, a.g.m., s. 176.

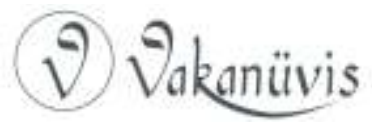


keyfiliğine bırakmalarını gerçekten bekleyemeyeceklerini, kendileri ve Türkiye'nin diğer müttefikleri için bunun kötü bir şey olmayabileceğini" yazdı. Türkiye, son zamanda hovardalıkla yapılan harcamaları durdurmaya kararlı, yüksek makamlardaki yozlaşmayı denetleyecek ve genelde Atatürk ruhuna geri dönecek sıkı disiplinle yönetilmeli, diye ekledi. $^{60}$

Britanya'da siyasete yön verenlerin Türkiye'nin demokrasi süreçleriyle yakından ilgilenmedikleri kolayca görülebilir. Aslında siyasal, ekonomik ve askeri alanlarda Britanya'nın çıkarlarına yoğunlaşıyorlardı. Türkiye'nin dış ilişkilerinde darbenin etkisi dikkat çekecek kadar azdı. Darbe yapıldığında Britanyalı siyasetçiler Türkiye'nin dış siyasetinde büyük bir değişiklik olmamasına sevindiler. Yeni hükümetin Türkiye'nin NATO ve CENTO'nun müttefiki olduğunu, Kıbrıs dâhil mevcut diğer uluslararası çözümlere bağlılığını vurgulayarak halka yapılan ilk duyuruyu gördüklerinde, özellikle Kıbrıs davasında Britanya'nın avantajları bulunduğunu anladılar. ${ }^{61}$

Burrows 21 Haziran 1960'da Sarper'le görüşmesinde seçim tarihini ve Demokratların gelecek seçime katılıp katılmayacaklarını özellikle öğrenmek istedi. Eski hükümet üyelerinin geleceğini de öğrenmeyi arzu etti. Sarper eski hükümet üyelerinin davasının tamamıyla tarafsız ve siyasal baskıdan uzak görüleceğinden söz etti. Burrows onun açıklamasına inanmadı, "Sarper'in davalarla ilgili sözlerinin doğru olma ihtimali o zaman düşündüğümden bile daha azdı" diye belirtti. Örneğin MBK'nın infaz edeceği idam cezası hükmünün, bütün sürecin MBK henüz baştayken tamamlanacağını netleştirir gibi göründüğünü öne sürdü. MBK'ne yakın bir kaynaktan, iktidarın devrinden önce duruşmaların bitmesini düşündüklerini de duymuştu. ${ }^{62}$

1960'da başa gelen rejim, Demokrat Parti'yi feshederken ve köylülerden oy almak için kullandıkları bazı yöntemleri çok eleştirirken, Anadolu'yu kentlerde ve Batı kıyısında ulaşılan kalkınma ve eğitim

60 FO371/153035/RK1051/x, Britanya Dışişleri Bakanlığı'ndan (Ross) Burrows'a, 29 Haziran 1960.

${ }^{61}$ FO371/160212/RK1011/1, Burrows'tan Britanya Dışişleri Bakanlığı'na, 6 Ocak 1961. Göktepe, a.g.m, s. 177.

62 FO371/153035/RK1015/40, Burrows'tan Britanya Dışişleri Bakanlığı'na (Ross), 21 Haziran 1960.

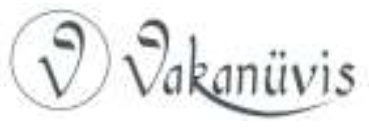


düzeyine getirmek gerektiğini anlamıştı. Bu yönde yaptıkları en dikkate değer hamle, askerlik hizmetini, eskiden subay olarak yapan lise mezunlarının bütün illerdeki ilkokullarda iki yıl ders vererek yapması oldu, başarılı gibi görünen bir sistem. Doğu illerindeki feodal toprak sahiplerinin güçlerine son vermek için $55^{\prime}$ ini ülkenin başka yerlerinde zorunlu ikamete güç kullanarak gönderip kararlı bir girişimde de bulundular. ${ }^{63}$

Ne var ki devrimci rejim çabasının büyük bölümünü eski rejimden son birkaç ayda geriye kalan karışıklığı düzeltip temizlemeye ve gelecek hükümetin demokratik olmayan böyle bir yol izlemesini daha az mümkün hale getirmeye yönlendirdiği için, olumlu başarıları genel olarak çok büyük değildi. Başarmak istedikleri ilk hedef yürürlüğe girecek son hedefti de, yani yeni anayasa taslağını hazırlamak. Profesörler komitesine ilk taslağı hazırlama görevi verildiği devrimin ilk gününden beri bu projenin özünde ve usulünde birçok değişiklik yapılmıştı. ${ }^{64}$

Genelde bir tür korporatif sistemle seçilmiş kurucu meclisin 1961 Ocak'ının başında toplantı yapmasında, 1961 Mayıs'ında referanduma başvurmak için nihai taslağı hazırlamasında, yıl içinde daha sonra yeni anayasaya göre ilk seçimlerin yapılmasında mutabık kalındı. Yeni anayasanın özünün ne olacağını söylemek için 1961 Ocak'ının başı bile henüz çok erkendi. Merkezi hükümetin fiili otorite uygulayıp uygulamayacağı kuşkusu bulunduğundan, yeni tek parti diktatörlüğü eğilimlerini önlemek için ilk temayül anayasayı birçok denge ve denetlemeyle doldurmaktı. ${ }^{65}$

Daha sonraki taslaklarda bu eğilim değişmiş gibi görünse de doğru denge bulundu mu, bulunmadı mı kesin değildi. Nispi temsil sistemi kurmak için temel değişiklikler yapılacağı hemen hemen kesindi.

63 Feroz Ahmad, Demokrasi Sürecinde Türkiye, 1945-1980 (Çev. Ahmet Fethi), İstanbul, 1996, s. 213. Hale, a.g.e., s. 118. FO371/160212/RK1011/1, Sir Bernard Burrows, “Annual Report on Turkey for 1960", Britanya Büyükelçiliği, Ankara, 6 Ocak 1961.

6427 Mayıs 1960'da Anayasa Komisyonu'na anayasayı düzenlemek için hemen çalışmaya başlama, dolayısıyla hemen bir sivil hükümet kurma talimatı verildi. Komisyona İstanbul Üniversitesi Rektörü Sıddık Sami Onar başkanlık ediyordu.

65 FO371/160212/RK1011/1, Sir Bernard Burrows, "Annual Report on Turkey for 1960", Britanya Büyükelçiliği, Ankara, 6 Ocak 1961.

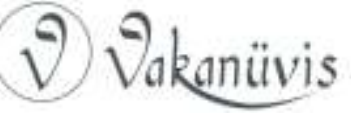


Toprak reformu, iş kanunu, ulusal sağlık hizmeti ve bazısı bizatihi arzu edilebilir olmakla birlikte, halkın seçtiği hükümetin uygulamaya koymasının güç olacağı başka birçok reform gibi, yeni rejimin uygulayabileceği veya en azından başlayabileceği uzun vadeli reformlardan da söz edilmişti. Ne var ki Kurucu Meclis göreve başlamadan önce bu önerilerin herhangi birinde fazla ilerleme kaydetmek o tarihte imkânsız gibi görünüyordu, Meclis'in birincil işlevinin, anayasayı yapmanın dışında başka temel yasaları yapmaya ayıracak yeterli zamanı bulup bulmayacağı kuşkuluydu. ${ }^{66}$

Burrows şu yorumu yaparak sonuca varır:

"Olumlu başarıları çok büyük olmamakla birlikte, siyasal tecrübesi bulunmayan ve heterojen askerlerden meydana gelen bir komitenin bu ülkenin işlerini aylardan beri daha büyük yanlışlar yapmadan yürütebilmesi dikkate değer ve Türkiye'de mevcut devletin herhangi bir değerlendirmesinin en umut verici özelliklerinden biri belki, oldukça sıradan Türklerden meydana gelen bu grubun, ülkelerinin durumu adına onu yönetmeye başlayacak kadar kendini yeterince güçlü hissetmesi, hükümet etmeyi herhangi bir pratik veya siyasal zorunluluktan önce, demokrasi adına bırakacak kadar kendini yeterince güçlü hissetmesidir." ${ }^{67}$

Devrimin ülkenin dışişlerine etkisi dikkat çekecek kadar azdı. Devrimci rejim, selefinin Batı yanlısı dış siyasetini devam ettirdi. Daha önce söz edildiği gibi, Menderes Sovyetlerle ilişkilerini yumuşatmaya çalışmış ama bu gerçekleşmemişti. Devrim hükümetinin ilk açıklamalarının hepsi pratikte Batılı müttefiklerine (NATO ve CENTO) sadık kaldığı ama kendi dışişleri siyasetini uygulamada biraz farklı olabildiği mealindeydi. Bu farkların, çoğunlukla Sovyetler ve Arap dünyası gibi komşu ülkelerle ilişkilerin daha esnek yürütülmesinde hissedilebildiği anlaşılıyordu ama herhangi bir değişikliği fark etmek zordu. Sovyetler durumunu geliştirmek için bunu fırsat bildi ve geniş çaplı ekonomik yardımla karşılıklı üst düzey ziyaretleri kabul etmeye ikna etmek için Türkiye'ye çok baskı yaptı, Türkiye ikisini de geri çevirdi

66 Zürcher, a.g.e., s. 257-259. FO371/160212/RK1011/1, Sir Bernard Burrows, "Annual Report on Turkey for 1960", Britanya Büyükelçiliği, Ankara, 6 Ocak 1961. Hale, a.g.e., s. 124-125.

67 FO371/160212/RK1011/1, Sir Bernard Burrows, "Annual Report on Turkey for 1960", Britanya Büyükelçiliği, Ankara, 6 Ocak 1961.

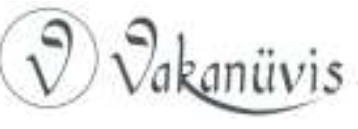


ve Batı'yla bağlantısını devam ettirme siyaseti zarar görmedi. Yine de, General Gürsel Krusçev'e bir mektubunda Sovyetlerle sınır ötesi ilişkilerin normalleştirilmesini kesin olarak belirtti. Türk hükümetinin Birleşik Arap Cumhuriyeti'yle ilişkilerinde eski tatsızlığı gidermek için bazı girişimlerde bulunduğu bellidir ama Suriye'de, daha sonra Mısır'daki uyanışla Arapların Hatay'ı istemesi bu alanda herhangi bir düzelme umudunu kırdı. ${ }^{68}$

Ekonomik meseleler açısından, devrimin sonuçları ticari durgunluğa istemeden yol açmakla birlikte hükümetin finansmanında çok olumlu olmuştu. Ekonomik meselelerde hoş olmayan olgularla yüzleşmeye ve daha ölçülü, daha gerçekçi bir çizgi izlemeye daha çok isteklilik göstermişti. Bakanların ve ileri gelen figürlerin demeçleri Türk halkına ilk kez içinde bulundukları ekonomik durumun ciddiliğini, finans işlerinin daha önce savurganlık ve tutarsızlıkla yürütüldüğü açıklamışlardı. Bütçe ekonomisi üzerinde çok duruldu, ekonomik kalkınma ve yatırımın ana çizgilerini oluşturmak için yabancı danışmanlarla birlikte planlama örgütü kuruldu. Avrupa iktisadi İşbirliği Örgütü'nün (OEEC) ve Uluslararası Para Fonu'nun (IMF) misyonları yıl içinde Türkiye'ye geldi ve 1960 Kasım'ında üst düzey temsilciler ortak bir ziyarette bulundular, sonucunda üyelerine, 90 milyon dolarlık havalenin ödeme dengelerinin açığını karşılamak için 1961'de

68 Zürcher, a.g.e., s. 255-256. Hale, a.g.e, s. 119-124. Ahmad, The Making of Modern Turkey, s. 167-170. F0371/160212/RK1011/1, Sir Bernard Burrows, "Annual Report on Turkey for 1960", Britanya Büyükelçiliği, Ankara, 6 Ocak 1961.

1960 Kasım'ında sürgün edilen Milli Birlik Komitesi'nin aşırı uçtaki 14 üyesi arasında doğrudan tartışılan meselelerden biri dış siyaset olmamakla birlikte, kazansalardı, hatta Komite'de kalsalardı Türkiye'nin dışişlerinde deneysel bir çizgi izlemesi ve Batı'nın daha az güvenilir bir partneri olması mümkündü. Belli belirsiz Afro-Asyatik kıpırtılar genç entelektüellerin gözüne çarpmaya başlamıştı; Cezayirlilere büyük ölçüde sempati vardı ve bu, Türkiye'nin Birleşmiş Milletler'de Cezayir konusunda Afro-Asyatik çözümden yana oy kullanmasına, başlıca kentlerde öğrenci gösterilerini desteklemesine neden oldu. Yine de bu duygu trendinin Türkiye siyasetinin genelini daha çok etkilemesi ihtimal dışı gibi görünüyordu. Bkz. FO371/160212/RK1011/1, Sir Bernard Burrows, "Annual Report on Turkey for 1960", Britanya Büyükelçiğili, Ankara, 6 Ocak 1961.

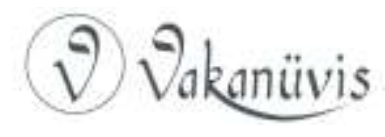


Türkiye'ye daha çok yardım yapmalarını tavsiye ettiler. Bu öneriler 1960 yılı sona ermeden hemen önce kabul edildi. ${ }^{69}$

$\mathrm{Bu}$ tavsiyelere eklenen Türkçe memorandum Türk hükümetinin finansal yapısına çeki düzen vermekte ve eskiden çok gevşek ve çok düzensiz unsurlardan biri olan devlet kurumlarını ilk kez denetim altına almakta kararlılığı gösteriyordu. Türk hükümeti ve örgütler bu ilave yardımla Türk ekonomisinin gelecekte kendisini döndürebileceğini söylemekten de ilk kez çekindiler. Ödemeler dengesindeki açığın muhtemelen yıllarca süreceği ve Türkiye'nin giderek artan iç tüketimini karşılamaya yetecek kalkınmaya ulaşmanın kolayca kestirme bir yolu, artı yeterli bir ihracat düzeyi bulunmadığı açıktı. Olgular rahatlatmıyordu, 1961'de Planlama Teşkilatı 1963-1968 yıllarının intiyaçlarıyla ilgili olarak muhtemelen problemlerin daha büyüyüp idarenin daha güç olacağı öngörüsünde bulunduğunda, Türklerle Batılı müttefikleri kendilerini neyin beklediğini daha net görebilsinler diye bunları ortaya koymak daha avantajlı gibi göründü. ${ }^{70}$

Eski Cumhurbaşkanı dâhil, eski hükümet üyelerinin, Meclis'teki DP üyelerinin, silahlı kuvvetlerin bazı üst rütbeli subaylarının ve DP'nin birçok destekçisinin 14 Ekim'de Yassıada'da başlayan davalarına gelince, yılsonunda karara varılmasının ihtimal dışı olduğu fark edilmektedir. Aslında, en önemli suçlamanın, suçlananların çoğu için idam cezasının talep edileceği anayasayı ihlal suçlamasının duruşması henüz başlamamıştı bile. Dava öncesi soruşturmaları askeri rejimin seçtiği otuz bir üyeden oluşan Yüksek Soruşturma Komisyonu yürüttü. Komisyon işini yürütürken dava dört aydan daha uzun süre ertelendi. On bir aylık sürede iki yüzün üzerinde oturum yapıldı. ${ }^{71}$

69 FO371/160212/RK1011/1, Sir Bernard Burrows, "Annual Report on Turkey for 1960", Britanya Büyükelçiliği, Ankara, 6 Ocak 1961, Hale, a.g.e., s. 118.

70 FO371/160212/RK1011/1, Sir Bernard Burrows, "Annual Report on Turkey for 1960", Britanya Büyükelçiliği, Ankara, 6 Ocak 1961, Hale, a.g.e., p. 118.

71 Hale, a.g.e., s. 129-130.

DP hükümetinin eski üyeleriyle milletvekillerinin mahkemesi darbeden dört buçuk ay sonra 14 Ekim 1960'da Marmara Denizi'nde Yassıada'da başladı. Dava 15 Eylül 1961'e kadar neredeyse on bir ay sürdü. Sanıklara eski Cumhurbaşkanı Celal Bayar, eski Başbakan Adnan Menderes, eski Parlamento sözcüsü Refik Koraltan, bütün kabine, DP'li bütün milletvekilleri, çok sayıda eski vali, eski Genelkurmay Başkanı, eylem özgürlüğünü kısıtlama vakalarına karışan yerel görevlilerle polisler, yolsuzluk vakalarına

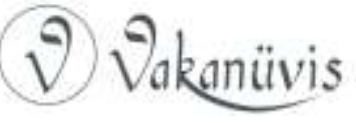


Yetkililerin davalara müdahale etmedikleri söylenemez. Yargıçları ve savcıları askeri komitenin oluşturduğu hükümet doğrudan atadı. Burrows şöyle yorumlar:

"Bu davalar konusunda dünyanın ne düşündüğü büyük ölçüde bunların sonuçlarına bağlı. Dolayısıyla, bunları uzun uzadıya tartışmanın zamanı değil. Davaların açılma nedenleri muhtelif. Belki en önemlisi devrimi meşrulaş̧ırma isteği. Türkler yasalara bağı bir halktır. Devrimcilerin, icraatları gayri meşru olmasına rağmen, bunların doğru olduğunu göstermek hoşlarına gitmiyor ama meşru olduğunu da kanıtlamak istiyorlar. Devirdikleri rejimin liderlerine ne yapacakları gibi zor bir soru da var. Pakistan devriminin Britanya hükümetine çok daha basit ve çok daha insani gibi görünen yöntemini, yani bu insanları bir süre siyasal yaşamdan uzaklaştırma, bu kararla mücadele etmek isterlerse hukuka başvurma imkânı verme yöntemini izlemek belki akıllarına bile gelmez. Fakat bunu yapmak akıllarına gelse bile, Menderes'i bu koşullarda bile serbest bırakmanın güvenli olmadığını muhtemelen hissetmiş olacaklar." ${ }^{172}$

Burrows'un analizi doğruydu, çünkü Rektör Profesör Onat dâhil, İstanbul Üniversitesi'nin hukuk hocaları MBK'ne darbeyi meşrulaştırmayı tavsiye etmişlerdi. Darbe yapıldığında subaylar yeniden seçime gitme, üç ay geçmeden yetkiyi sivil hükümete bırakma niyetindeydiler. Akademisyenler eski hükümetin bakanlarıyla DP'li üyeler tutuklanıp suçlu bulunmazlarsa yeniden seçilme hakkı kazanacaklarını, yeniden hükümet kurabileceklerini belirterek, darbe liderlerini yeni seçimler yapılmadan önce yargılamaya MBK'ni teşvik ettiler. Entelektüellerin doğru bir hukuki süreç izleme tavsiyesi sonucu neredeyse on bir ay geciktirdi. MBK kısa bir dava sonucunda eski hükümet üyelerinin hızla bertaraf edilebileceğini düşünmüş gibi görünüyordu. Mahkeme karara varmaksızın davaların uzaması seçimlerin ve sivil rejime dönüşün gecikmesine neden oldu. ${ }^{73}$

Bazı entelektüellerin darbeyi doğrudan destekledikleri ve tavsiyelerinin basit bir darbeyi "devrime" dönüştürdüğü öne

karışan bazı işadamları dâhildi. Çoğu, 1960 Haziran'ının başından itibaren adada hapsedildi.

72 FO371/160212/RK1011/1, Sir Bernard Burrows, "Annual Report on Turkey for 1960", Britanya Büyükelçiliği, Ankara, 6 Ocak 1961.

73 Göktepe, a.g.m., s. 179.

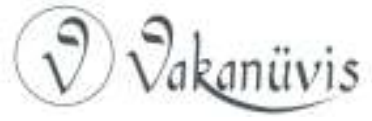


sürülebilir. MBK mevcut anayasayı yürürlükten kaldırdı, yeni anayasanın bir komisyon tarafından hazırlanmasını istedi. Eski anayasaya göre kendilerinin suç işlediklerini anladıkları için onu değiştirdiler ve ordunun hem eski hem de yeni anayasaya göre vatanseverlik görevini yerine getirmekten başka bir şey yapmadığını öne sürdüler. ${ }^{74}$

Irak örneği hafızalarda henüz tazeyken devrimciler devrimin ilk heyecanıyla muhaliflerini öldürmeyi aynı nedenle istemediler. Tek alternatif sonuçta eski liderlerin ya yasaya uygun şekilde infaz edilecekleri ya da güvenli sayılan bir süre için halkla temaslarının kesilerek mahkûm edilecekleri bir hukuki süreç başlatmaktı. Diğerleri davanın caydırıcı olduğunu düşündüler, gelecekte siyasetçilerin siyasal suçun cezasının er geç verildiğini anlamaları için bunun gerektiğine inandılar. Başka bir motif DP'yi ve Menderes'i destekleyenlerinin, özellikle kırsal kesim seçmenlerinin gözünde küçük düşürmekti. Devrimciler ve onları destekleyen entelektüeller, Menderes'in, 1959'da uçak kazasından görünüşte mucizevi kurtulmasının ${ }^{75}$ pekiştirdiği neredeyse dinsel atıflar dâhil, çevresinde oluşturulan mitin çok farkındaydılar.

Britanya hükümeti sadece bu maksatla daha önemsiz birçok suçlama da getirildiğini düşünüyordu. Ancak bunların bazısı sonuçsuz kalabilirdi. Burrows, genel kanıya göre, eski rejimin siyasal doğada ciddi suçlar işlediğine ve mahkemenin işlevinin bu suçların işlendiğini veya işlenmediğini söylemek değil, kimin işlediğini, sanıkların ne derece suçlu olduklarını ve cezalarının ne olacağını söylemek olduğuna inanıyordu. Burrows'un fikrince, yargııın davranışı ve savunma için tanınan veya tanınmayan imkânlar bu genel kanıya uygundu, "Dinlenen kanıt Britanya standartlarına göre en çirkin dedikodu veya görüş

74 Hikmet Özdemir, Rejim ve Asker, İstanbul, 1989, s. 217-219. Birand, Dündar, Çaplı, a.g.e., s. 215.

75 Menderes 17 Şubat 1959'da Londra Konferansı'na giderken Gatwick Havaalanı yakınında uçağı düştü. Menderes kazadan kurtuldu ama on iki yolcu öldü. Menderes'i yurda dönüşünde büyük kalabalıklar, muhalefet lideri İnönü de Ankara istasyonunda karşıladı. El sıkıştılar, İnönü Menderes'ten iyi dileklerini kabul etmesini istedi. İki lider son defa el sıkışıyordu. Darbeden önce dostça koşullarda bir daha asla karşılaşmayacaklardı.

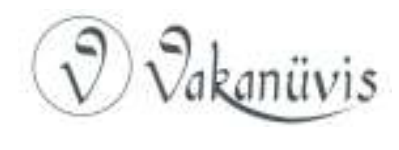


ifadesiydi."76 Burrows yargıcın sorularının arasına siyasal yorumlar kattığının, hatta izleyicilerin katılmasına izin verildiğinin görüldüğünü belirtti; yine de tek tek sanıklara tanıklara soru sorma fırsatı ve kendilerini savunurlarken uzun konuşma izin verildi. Ne var ki savunma avukatlarıyla müvekkillerinin istişare imkânları davalar devam ederken biraz düzelmekle birlikte normal standartlara göre yine de yetersizdi. ${ }^{77}$

1961'in ilk altı ayında Britanya hükümeti, kurucu meclisin tam olarak siyasal yaşamı yavaş yavaş yeniden başlatacak yeni nihai anayasayı halkın onayına sunma sorumluluğu kadar geçici parlamento yetkilerine de sahip olmasını beklemişti. Bu kurucu meclis iki organdan Milli Birlik Komitesi ve diğer siyasal partilerin (CHP ile Cumhuriyetçi Köylü Millet Partisi) 272 temsilcisinin oluşturduğu temsilciler meclisinden, profesyonel gruplarla illerin az çok bağımsız temsilcilerinden meydana geliyordu. Eski muhalefetin, CHP'nin, nüfuzunun muhtemelen güçlü olacağı görülüyordu. Bu meclisin çalışmasının onları strese sokacağı beklenmekle birlikte, demokrasiye geçişi güvenle sonuçlandırmak için muhtemelen daha iyi olduğu düşünülüyordu. Demokrasinin, bir kez kavuşuldu mu sürüp sürmeyeceği daha az kesindi. ${ }^{78}$

1961 yılı benzersiz karakterde bir dizi siyasal olayın yılıydı. Türkiye yıla iktidarda bulunan askeri rejimle girdi, yeni bir demokratik anayasa hazırlandı, eski Başbakanla ileri gelen yardımcılarından ikisi kanuna uygun olarak infaz edildi, en sonunda özgür seçimler yapıldı, sonuçta iktidar, siyasal mücadeleleri 1960 devriminin başlıca nedeni olan keskin muhalif iki partinin eşit sayıda temsilcisinden oluşan koalisyon hükümetine devredildi. Burrows bu olayları aşağıdaki gibi yorumlar:

"Bu gelişmeler Türk halkının ve devletinin gericiliğiyle ilericiliğinin, hizipçiliğiyle disiplininin birçok zıtlığıyla birlikte paradoksal yapısına çok keskin işaret ediyor, özellikle bir yandan kanunlara bağı ıalmanın güçlü eğilimiyle, öte yandan ulusal çıkarı dayatmak için kuvvet

76 FO371/160212/RK1011/1, Sir Bernard Burrows, "Annual Report on Turkey for 1960", Britanya Büyükelçiliği, Ankara, 6 Ocak 1961. Zürcher, a.g.e., s. 256-261.

77 FO371/160212/RK1011/1, Sir Bernard Burrows, "Annual Report on Turkey for 1960", Britanya Büyükelçiliği, Ankara, 6 Ocak 1961. Zürcher, a.g.e., s. 256-261.

78 FO371/160212/RK1011/1, Sir Bernard Burrows, "Annual Report on Turkey for 1960”, Britanya Büyükelçiliği, Ankara, 6 Ocak 1961. Zürcher, a.g.e., s. 256-261.

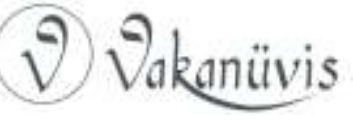


kullanmaya veya kuvvete güvenmeye hazır olma arasındaki zıtlığı net olarak aydınlatıyordu." 79

1961'de başlıca olay Yassıada davalarının sonuçlanmasıydı. Davalar, birçoğu daha önceki suçlamalarla ilişkisiz olmaktansa, Anayasa'yı veya siyasal iktidarı kötüye kullanmakla doğrudan ilişkilendirilen olaylarla yılın ilk sekiz ayı boyunca sürdü. Bilgisiz gözlemcinin üzerindeki genel izlenim, sonunda, başlangıçta bilinenden daha fazlasının ortaya çıkmadığı veya kanıtlanmadığı ama mahkemede ortaya koyulan bu bilinen olguların bazısının siyasal açıdan ciddi olduğu yönündeydi. Burrows şu yorumu yapar:

"Konuyla ilgili, önde gelen nokta, Demokrat Parti'nin kendi çoğunluğunu parlamento, basın ve ülkede siyasal tartışmayı Anayasa'nın kelimesi kelimesine olmasa da ruhuna kesinlikle aykırı bir tarzda kullanmasıydı. Demokrat Parti'nin muhaliflerinin bunun siyasal mücadelenin normal iniş çıkışlarını aşan bir suç olduğuna inanmaları şaşırtıcı ve ille de menfur değil. Türklerin meşruluğu aşırı düşünmeleri eski Anayasa'da, Anayasa'yı zor kullanarak yıkmaya çalışan birine idam cezası vazeden bir maddenin az çok rastlantı eseri yer almasıyla birleştiğinde, bu siyasal aşırılığın öcünü almak isteğiyle hukuka başvurmanın dayanılmaz çekiciliği vardı." 80

Mahkemenin ülkeye veya en azından yargıçların ait oldukları toplum düzeylerine yayılmış devrimci duygudan etkilendikleri ve "masumluğa veya suçluluğa karar vermemek ama cezaları doğru ölçülerde paylaştırmaya" kendi görevleri gözüyle baktıkları sonucunu çıkarmak da kolaydır. ${ }^{81}$

Britanya hükümeti Türkiye'nin durumuyla ilgileniyordu. Duruşmalar başladıktan kısa süre sonra Burrows davalarla ve muhtemel kararlarla, özellikle eski Başbakanı ve diğer bakanları etkileyenlerle ilgili düzenli gönderiler gönderdi. Türk Dışişleri Bakanı Sarper 25 Kasım 1960'da Ankara'da yabancı temsilcilerle görüştü ve Türkiye'nin duyarlılıklarını

79 FO371/163832/CT1011/1, Sir Bernard Burrows, "Annual Report on Turkey for 1961", Britanya Büyükelçiliği, Ankara, 22 Ocak 1962. Zürcher, a.g.e., s. 256-257.

80 FO371/163832/CT1011/1, Sir Bernard Burrows, "Annual Report on Turkey for 1961", Britanya Büyükelçiliği, Ankara, 22 Ocak 1962. Zürcher, a.g.e., s. 256-257.

81 FO371/163832/CT1011/1, Sir Bernard Burrows, "Annual Report on Turkey for 1961", Britanya Büyükelçiliği, Ankara, 22 Ocak 1962. Zürcher, a.g.e., s. 256-257. FO371/160214/RT1016/49, Burrows'tan Britanya Dışişleri Bakanlığı'na, 3 Mart 1961.

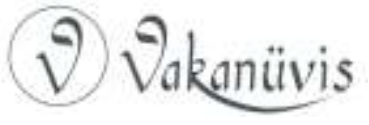


hesaba katarak, durumun en iyi şekilde nasıl ele alınacağını anlattı. 0 tarihte Britanya Dışişleri Bakanlığı'nda Güney Dairesi'nin Başkanı olan R. F. G. Sarell Sarper'in tavsiyelerini hükümetine bir notta özetledi: "idam cezalarıla ilgili fikirler belirtmemek, çünkü bunlar infazlara çok karşı olduğunu bizzat ifade eden General Gürsel'in canını sıkar, onu rahatsız eder sadece." ${ }^{\prime 2}$ Anlatıldığına göre, Sarper'e, idam cezası infaz edilirse istifa etmeye çoktan karar verdiğini söylemiş, bundan daha öteye gidemediğini eklemişti. Sarper idam cezası vermeme ihtimalinin yarı yarıya olduğunu ve verildiği takdirde infazın aleyhine 80/20 ihtimal bulunduğunu tahmin ediyordu. Burrows da bu gelişmeleri bildirdi ve aynı belgede Britanya Dışişleri Bakanlığı'nın bir görevlisinin yazdığı tutanak vardı: "Çok ilginç. Sarper'in tavsiyesine uyacağımızdan eminim. Bunu görmek Başbakan'ın ilgisi çekebilir." 83 Britanya Dışişleri Bakanlığı Başbakan'a bir gönderi gönderdi ve şunu vurguladı: "Sanki olaylar şu anda istediğimiz yolda gidiyor gibi geliyor. Daire'nin bakış açısı, Sarper'in tavsiyene kuşkusuz uymamız gerektiği yönünde." 841960 Kasım'ında Başbakan Macmillan, General Gürsel'e Yassıada davasıyla ilgili olarak, Burrows'un teslim edeceği şahsi bir mesaj göndermeyi kabul etti..$^{85}$

Herhangi bir değişiklik yapma ve Gürsel'e ne zaman ve nasıl teslim edeceğine karar verme inisiyatifi Burrows'un takdirine bırakıldı. Bu durumda, dava muhtemelen aleyhte kararların verileceği sonuna yaklaşırken, Burrows mesajı 4 Ağustos 1961'de vermeden önce dokuz ay bekledi. Mesajda başlıca konular şöyleydi:

Bu, Türkiye'nin iç hukukuyla ilgili bir mesele, davaların veya kararların sürecini yorumlamak bize uygun değil. Başbakan, General

82 FO371/153038/RK1018/83, Burrows'tan Britanya Dışişleri Bakanlığı'na, 26 Kasım 1960. PREM11/4552, Britanya Dışişleri Bakanlığı'ndan Başbakan'a, 30 Kasım 1960. FO371/160214/RT1016/49, Burrows'tan Britanya Dışişleri Bakanlığı'na, 3 Mart 1961. 83 FO371/153038/RK1018/83, Burrows'tan Britanya Dışişleri Bakanlığı'na, 26 Kasım 1960. PREM11/4552, Britanya Dışişleri Bakanlığı'ndan Başbakan'a, 30 Kasım 1960. FO371/160214/RT1016/49, Burrows'tan Britanya Dışişleri Bakanlığı'na, 3 Mart 1961. 84 FO371/153038/RK1018/83, Burrows'tan Britanya Dışişleri Bakanlığı'na, 26 Kasım 1960. PREM11/4552, Britanya Dışişleri Bakanlığı'ndan Başbakan'a, 30 Kasım 1960. FO371/160214/RT1016/49, Burrows'tan Britanya Dışişleri Bakanlığı'na, 3 Mart 1961. 85 FO371/153038/RK1018/83, Burrows'tan Britanya Dışişleri Bakanlığı'na, 26 Kasım 1960. PREM11/4552, Britanya Dışişleri Bakanlığı'ndan Başbakan'a, 30 Kasım 1960. FO371/160214/RT1016/49, Burrows'tan Britanya Dışişleri Bakanlığı'na, 3 Mart 1961.

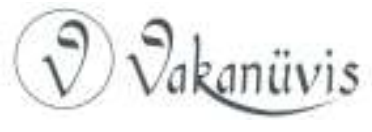


Gürsel'in dikkatini infazların Birleşik Krallık'ta muhtemelen yaratacağı etkiye çekmeyi arzu ediyor sadece. Türkiye'yle dostluğumuza ve ittifakımıza çok önem veriyoruz. Menderes ve meslektaşları Türkiye'nin Batı'yla bağlantısının, NATO ve CENTO'nun güvenilir destekçileri olarak tanınıyordu. KIBRIS meselesinin çözümünde önemli rol oynadılar. Birleşik Krallık'ta bu insanların infazına, Türkiye'nin ve Birleşik Krallığı'n ait olduğu Batı topluluğunun yüce ideallerine aykırı diye bakılacaktır. ${ }^{86}$ Burrows mesajın kilit askeri personel arasında çok yayıldığını bildirdi. Britanya Dışişleri Bakanlığı iyimserlikle, mesajın önemli etki yarattığı yorumunu yaptı. ${ }^{87}$

Britanya Dışişleri Bakanlığı Burrows'a daha önce karışmamasını, Türkiye'ye yabancı müdahale suçlamalarıyla iyilikten çok kötülük yapma tehlikesinden sakınmak için mümkün olan son ana kadar beklemesi tavsiye etmişti. Gönderiye göre, her halükârda bu tehlikeye karşı önlem alması söylenmişti, muhtemel hükümlerin aşırı katılığının Batı dünyasında Türkiye'nin dostları üzerinde etkisi vurgulanacaktı. Bu durum, Ankara'daki yabancı temsilcilerin ve Britanya hükümetinin temasta bulunduğu $A B D$ dâhil, diğer hükümetlerin genel görüşleriyle aynı doğrultuda gibi görünüyordu. Burrows'tan başlıca müttefik meslektaşlarıyla temasını sürdürmesi istenmiş, Britanya Dışişleri Bakanlığı İran'ın Ankara Büyükelçisi'nin de Burrows'la yakın temasını sürdürmesini önermişti. ${ }^{88}$

Macmillan'ın mesajı fiilen iletilmeden önce bile Britanya hükümeti görüşünü Türk yetkililere mümkün olan her fırsatta açıkladı. Şimdi Britanya Maliye Bakanı olan eski Dışişleri Bakanı Selwyn Lloyd 1960 Aralık'ında OECD toplantısında Türk Dışişleri Bakanı Sarper'le görüştü. Lloyd Sarper'e davayı sordu. Sarper, sanıklara her imkânın ve adil yargının sağlandığını söyledi. Sarper, General Gürsel dâhil, cuntanın güçlü bir kesiminin idam cezası verilmesine karşı olduğundan söz etti. Lloyd bunu duyunca rahatladığını söyledi, idamlar yapılsaydı Türkiye için trajedi olurdu, diye düşündü. Yargılananların Batı'nın iyi dostları olduklarını da vurguladı. Sarper tamamıyla aynı fikirde olduğunu

86 FO371/160214/RT1016/49, Burrows'tan Britanya Dışişleri Bakanlığı'na, 3 Mart 1961. ${ }^{87}$ FO371/160791, Merkez Daire'den E. E. Tomkins'in tutanağı, 8 Eylül 1961.

88 FO371/153038/RK1016/18, Britanya Dışişleri Bakanlığı'ndan Tahran'a, 15 ve 25 Kasım 1960.

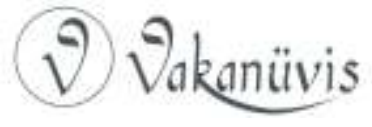


söyledi, İngiliz bakana gerçekten infaz edilecek hiçbir idam cezasının olmayacağının güvencesini verebileceğini düşünüyordu. ${ }^{89}$

Burrows davaların sonunda muhtemel ölüm cezalarıyla ilgili olarak, Ankara' da müttefik ülkelerin misyonlarıyla yakın ilişkilerini sürdürürken Britanya Dışişleri Bakanlığı da müttefik misyonlarla temaslarını sürdürüyordu. Almanya Büyükelçisi 7 Kasım 1960'da Daimi Müsteşar Hoyar Miller'la görüştü. Zamanından önce herhangi bir müdahalenin hata olacağına ve herhangi bir açıklamanın muhtemelen çok etkili olacağı zamana kadar geciktirilmesine karar verdiler. Miller, Alman hükümetinin bu meseleyi Türkiye'yle ekonomik ilişkilerine bağlamayı düşündüğüne Britanya hükümetinin bir zamanlar inandığını ekleme fırsatı buldu. Iki konuyu birbirine bağlamanın yanlış olacağını, Türk hükümetine böyle bir baskının kendi kendini engelleme olabileceğini de düşünüyordu. Almanya Büyükelçisi bunu anladığını söyledi ve Alman hükümetinin artık bu fikirden vazgeçtiği izlenimini verdi. ${ }^{90}$

Amerika'nın Ankara Büyükelçisi Fletcher Warren, Burrows'a, darbenin ilk günlerinde Gürsel'e infazların Amerika'nın görüşünü kötü etkileyeceğini, dolayısıyla, Kongre'nin Türkiye'ye yardımı onaylamasının ABD hükümeti için daha güç olacağını söylediğini anlattı. Burrows Almanlarla Fransızların Ortak Pazar müzakeresi vasıtasıyla Türkleri bu konuda etkilemeye çalışabileceklerinden de söz etti. Ankara'ya bu ekonomik baskıyı yapmaya çalışmanın büyük bir hata olduğunu düşündüğünü belirtti. Aslında Fletcher Warren'ın bunu yapacak kadar akıllı olduğundan kuşkulanıyordu, "Türkler çıkarcı ekonomik mülahazalar karşısında onurlarında diretmeyi sevecek kadar oryantaldirler. Uygar bir millet olarak prestijlerine hitap etmek muhtemelen daha başarılı olur" ${ }^{\prime 11}$ diye ekledi.

Türk hükümeti daha önce Ankara'daki yabancı misyon başkanları davalara katılsınlar diye davetiye çıkarmıştı. Britanya Dışişleri Bakanlığı

89 FO371/153036/RK1015/71, Britanya Dışişleri Bakanlığı'ndan Ankara'ya, 16 Aralık 1960.

90 FO371/153037/RK1016/11, Britanya Dışişleri Bakanlığı'ndan (Sarell) Burrows'a, 7 Kasım 1960.

91 FO371/153037/RK1018/1, Burrows'tan Britanya Dışişleri Bakanlığı'na(Ross), 21 Ekim 1960.

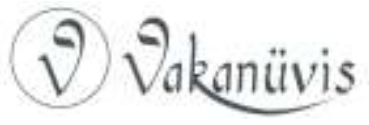


bu durumla ilgili olarak Burrows'a bir gönderi gönderdi, müttefik dost misyonlarla, özellikle ABD'li meslektaşıyla koordine olmasını vurguladı:

"Böyle bir işbirliği koşuluyla, Ekselanslarının şahsen katılmasının uygun olduğunu düşünmüyorum ama onun kadrosundan gözlemci olarak biri sizi temsil ederse hiçbir sakınca görmüyorum, aslında avantajlı buluyorum. Bu katılma mevcut Türk yetkililerine herhangi bir saygısızlığı önler ve onun, davaları veya sonucunu onayladığını ima etmeksizin yargılama usullerinin doğru bir değerlendirmesini yapmasını sağlar." 92

Göktepe'nin belirttiği gibi, bu mesaj askeri darbeyi ve eski hükümet üyelerini suçlamak için kurulan türde özel bir mahkemeyi onaylamaktan kaçınırken mevcut Türk hükümetiyle iyi ilişkilerini sürdürmek isteyen Britanya hükümetinin ikilemini göstermektedir. Britanya hükümeti askerin idare ettiği hükümetin muhtemelen bir süre iktidarda kalacağını hesaplıyordu. Stratejik ve ekonomik nedenler, CENTO ve NATO üyeliği ve Kıbrıs meselesi göz önüne alındığında Britanya hükümeti mevcut Türk hükümetiyle iş yapmaya devam edecekti. Britanya'nın çıkarları göz önüne alındığında bu politika anlaşılabilirdi ama insani veya ahlaki bakış açısından Britanya hükümeti ödün veriyordu. Britanya Dışişleri Bakanlığı aynı gönderide Burrows'a idam cezaları onaylanırsa nasıl tepki göstereceği talimatını da verdi. ${ }^{93}$

Burrows 3 Mart 1961'de Türk Dışişleri Bakanı'nın çok güçlü bir tavsiyede bulunduğundan söz etti. Sarper, Kraliçe Gürsel'e 6 Mart'ta Ankara'da görüştüklerinde, eski cumhurbaşkanı, başbakan ve diğerleri Yassıada davası sonucunda infaz edilirlerse yurt dışında yol açacağı kötü izlenimi bizzat söylerse çok yararlı olacağını vurguladı. Burrows Majesteleri için bu tür mesele hakkında konuşmanın çok olağandışı olacağını düşündüğünü ama 24 Mart 1961'de Miller'a bu konuda şahsi bir mesaj göndereceğini söyledi. Sarper böyle bir öneride bulunduğunun bilinmemesinin kendisi için hayati önem taşıdığının altını çizdi. ${ }^{94}$

92 FO371/153037/RK1016/11, Britanya Dışişleri Bakanlığı́ndan (Dışişleri Bakanı adına) Burrows'a, 10 Ekim 1960.

93 Göktepe, a.g.m., s. 183.

94 FO371/160214/CT1016/49, Burrows'tan Britanya Dışişleri Bakanlığı'na (H. Miller, şahsi), 3 Mart 1961.

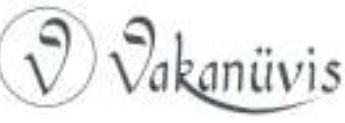


Majestelerinin uçağı Tahran'dan Londra'ya giderken Ankara havaalanında durduğu sırada Kraliçe havaalanının bekleme salonunda General Gürsel'le kısa bir sohbet yaptı. Edinburgh Dükü ve Home Kontu Prens Hazretleriyle Selim Sarper de hazır bulundu. Gürsel'e Türkiye'nin siyasal durumunu sorduklarında Gürsel planlarının doğru yolda ilerlediğini söyledi. Ayrıca şunları söyledi: Hukuk kuralları yerine getirilirken müdahale yapılamazdı. Savunma avukatları iyiydiler ve yargıçlar Türkiye'nin en iyileriydiler. Mesele onların vicdanına bırakılmalıydı. Fakat karar bizzat kendisinin ve MBK'nın değerlendirmesine bağlıydı. Gerekirse ve doğru olursa ancak o zaman özel aftan yana müdahalede bulunma fırsatı olacaktı. ${ }^{95}$

Mahkemenin sonucunu kuşkusuz öngöremiyordu ama hükümetinin kansız bir devrim yaptığını söylüyordu, kansız devam ettirmek istiyorlardı. Prens Philip Türkiye'nin yurt dışındaki birçok dostunun özel affı belirtecek bir kararı kuşkusuz iyi karşılayacağını öne sürdü. Türkiye'yle Britanya devlet başkanları arasında bu şimdiye kadar yapılmış olan ilk resmi görüşmeydi. ${ }^{96}$

Daha önce söz edildiği gibi, 1960 Kasım'ında Dışişleri Bakanlığı Başbakan Macmillan'ın General Gürsel'e mesajını Burrows'a göndermiş, ona dilediği zaman iletme yetkisi vermişti. Burrows infazların arzu edilmediği görüşlerini destekleme zamanının geldiğini düşündü. Duruşmaların son günü, 4 Ağustos 1961'de Burrows, Başbakan'ın Gürsel'e mesajını Sarper'e verdi. Nihai kararlar Eylül ortasında açıklandı. Mesaj, Sarper'in bir devlet başkanından aldığı ikinci yazılı mesajdı. Illki Alman Başbakanı Adenauer'dandı. Sarper Burrows'a Almanya'nın mesajının konuya Ingilizlerden biraz farklı bir bakış açısından yaklaştığını söyledi ama etkili ve potansiyel yararlı gözüyle baktığı izlenimini verdi. Görüşmede Sarper Burrows'a MBK'nın iç durumunu ve muhtemelen ne olacağını açıkladı. Orduda, kendini ordunun gerçek temsilcisi diye tanımlayan, Silahlı Kuvvetler Birliği

95 FO371/160217/RK1052/2G, Britanya Dışişleri Bakanlığı'ndan Burrows'a, 7 Mart 1961.

96 FO371/160217/RK1052/2G, Britanya Dışişleri Bakanlığı'ndan Burrows'a, 7 Mart 1961. Kral VIII Edward Atatürk'le 1936'da İstanbul'da baş başa görüştü ama Britanya'nın hiçbir monarkı "hâlâ sade olan başkent Ankara'yı" ziyaret etmemişti. Kraliçe askeri hükümet darbesinden sonra Türkiye'yi ilk ziyaret eden yabancı devlet başkanıydı da. Bkz. The Times, 7 Mart 1961.

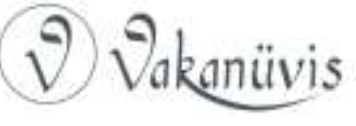


(SKB) adıyla bilinen örgütlenmiş başka bir grup bulunduğunu belirtti. Sarper onların muhtemelen MBK'ni gölgede bıraktıklarından ve bazı infazların yapılmasını istediklerinden söz etti. Sarper infazlara hâlâ karşı olan MBK üyelerini teşvik etmek için dışarıdan yardım istedi. ${ }^{97}$

Yargıçlar 15 Eylül'de kararlarını verdiler. 15 idam cezası vardı, dördü oybirliğiyle, geri kalanı oy çokluğuyla kabul edildi. Yassıada yargıçlarının oybirliğiyle karara vardıkları bu davalardaki idam cezalarını MBK on dörde sekiz çoğunlukla onayladı. Yargıçların çoğunun oyuyla hüküm giyen on birinin müebbet hükmünü MBK onayladı. Oybirliğiyle idam cezası verilen dört kişi eski Cumhurbaşkanı Celal Bayar, eski Başbakan Adnan Menderes, Dışişleri Bakanı Zorlu ve Maliye Bakanı Polatkan'dı. Bayar, hüküm tarihinde 78 yaşında olduğu için, yaşıı̆ı̆ı nedeniyle infazdan kurtuldu. İdam cezalarının hepsi Türk Ceza Kanunu'nun, "Türkiye Cumhuriyeti Teşkilatı Esasiye Kanununu tağyir ve tebdil veya ilgaya cebren teşebbüs edenler" için idam cezasını emreden 146. maddesine göre verildi. Mahkeme, davalarda bilirkişilerin çelişkili kanıtlarına rağmen bu suçun sabit olduğunu savundu. ${ }^{98}$

Britanya Dışişleri Bakanlığı idam cezaları raporlarını ve bunların 24 saat içinde yerine getirileceği hükmünü görünce bir gönderi gönderdi. Burrows'a, herhangi bir etkisi olacağını düşünüyorsa mesajı iletmesi talimatını verdi. Bunun üzerine Burrows mesajı hemen Gürsel'e verdi:

"Son mektubumda size ifade etmeye cüret ettiğim devlet davalarıla ilgili görüşleri Ekselansları kuşkusuz hatırlayacaktır. İngiltere-Türkiye dostluğunun ve genelde Batı ittifakının çıkarları açısından, bu argümanlar şimdi bana özellikle yerinde gibi geliyor. Ekselanslarının ayrıca bu mesajı gönderirken içinde bulunduğum ruh halini anlayacağına güveniyorum. Harold Macmillan." 99

$A B D$, Britanya, Almanya, Fransa ve Pakistan hükümetleri mahkemenin kararlarını duyar duymaz Gürsel'e infazı ertelemesini tavsiye eden mesajlar gönderdiler. İnönü, Türkeş, ABD Başkanı

97 FO371/160214/RT1016/49, Burrows'tan Britanya Dışişleri Bakanlığı'na, 3 Mart 1961. FO371/160791/CT1016/17, Burrows'tan Britanya Dışişleri Bakanlığı'na, 5 Ağustos 1961.

98 Göktepe, a.g.m., s. 186. The Times, 15 Eylül 1961

99 FO371/160224, No: 1921, Britanya Dışişleri Bakanlığı'ndan Burrows'a, 15 Eylül 1961. Eski Britanya Başbakanı Sir Winston Churchill de Gürsel'e benzer bir mesaj gönderdi.

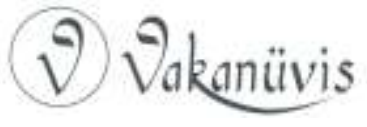


Kennedy, Kraliçe Elizabeth, Adenaeur, De Gaulle ve Menderes'le Bayar'a, sürgüne gönderileceklerse iltica teklif eden Eyüp Han'dan MBK'ne özel af başvuruları yağdı. Ne var ki MBK hepsini görmezden geldi. Majestelerinin hükümetinin mesajının ve diğer mesajların MBK'ni etkilemesi için artık çok geçti. ${ }^{100}$

ABD, Britanya, Almanya, Fransa ve Pakistan gibi yabancı hükümetlerin başkanları General Gürsel'e kararları ertelemesi için son anda mesajlar gönderdiler ama MBK üyeleri bunları görmezden geldiler. Bu hükümetlerin manevraları bakanların yaşamlarını bile korumakta çok geç kaldı. Yabancı hükümetlerin, özellikle Britanya'nın Türkiye'nin içişlerine karışıyor gibi görünmeyi hiç istemediklerini belirtmek de önemlidir. Britanya hükümeti mevcut şartlarda daha fazlasını yapabilecek olsa bile algılanan kaçınılmaz ulusal çıkarları önce geldi. Yine de Britanya medyası infazların acımasız olduğuna hüküm verdi. The Sunday Telegraph Nuremberg davasıyla aynı önemde gibi görünen dava maratonunun tarafsız bir hukuku süreç değil, siyasal eğilimli olduğunu belirtti. ${ }^{101}$

Bunun birçok nedeni vardı. Birincisi, Ankara'daki yabancı misyonlar mesajlarını doğrudan Gürsel'e vermektense Sarper'e verdiler. İkincisi, Gürsel MBK'de otoritesini çoktan kaybetmişti. Üçüncüsü, Genelkurmay Başkanı Sunay idam cezalarının onaylanmamasının orduda "hoşnutsuzluk" yaratacağını zaten vurguluyordu. Dahası, yurt dışından gelen mesajları MBK üyeleri okumadılar ama anlaşılan masanın üzerinde bıraktılar. Sonuncusu, ordudaki radikal gruplar MBK'ne baskı yapabildiler. Komitedeki generaller infazlara karşı olmakla birlikte, ast rütbeli üyeler infazları desteklediler. ${ }^{102}$

Sonuç eski Cumhurbaşkanı, Başbakan, üst düzey hükümet üyeleri ve parti yöneticileri dâhil, on beş sanığa idam cezası, DP'li neredeyse bütün milletvekilleri dâhil diğer 400'üne farklı sürelerle hapis cezası verilmesi oldu. Bu konuda kendine verdiği yetkiler uyarınca, ölüm cezalarının onaylanması veya hafifletilmesi için MBK'ne gönderilmesinin ardından en önemli aşamaya gelindi. Burrows,

100 Amerika Birleşik Devletleri Dış iliş̧kiler (FRUS), Cilt XVI, 1961-1963, Washington 1994, s. 709. The Daily Telegraph, 18 Eylül 1961. Göktepe, a.g.m., s. 187.

101 The Sunday Telegraph, 17 Eylül 1961.

102 Göktepe, a.g.m., s. 187. Hale, Turkish Politics, s. 144.

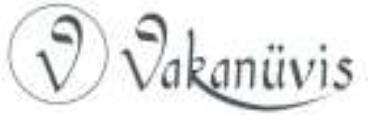


Britanya hükümetinden gelen dâhil, yabancı temsilcilerin ilettikleri özel aftan ve yurt içinde muhtemelen meydana gelecek sonuçlarına dair anlayışlarından etkilenen MBK'nın, yapılan tartışmada ölüm cezalarının hepsini hafifletmekten yana olduğunu sanıyordu. ${ }^{103}$

Askeri hükümetin, "eylemlerinin hiç kimsenin veya sınıfın lehine veya aleyhine olmadığı" yolunda halka ilk duyurusuyla Yassıada davalarının karara bağlanması arasında bir tezat vardı. Sanıklar sadece eski hükümet partisinin üyeleriyle onları destekleyenlerdi. Bu, darbenin kuşkusuz DP'ye karşı olması demekti. Ne var ki askeri hükümetin başındaki General Gürsel eski bakanların herhangi birinin infaz edilmeyeceğini vurguluyordu. ${ }^{104}$

Yine de bu arada, Komite üyelerinin yıl içinde siyasal sorumlulukları sırasında aralarının açıldığı Silahlı Kuvvetler'den yeni bir aktivist grup bütün idam cezalarının uygulanması gerektiğinde daha kararlıydı. General Gürsel, son ana kadar bu grupların ikisinin de diğerinin fikrini muhtemelen tam olarak bilmiyor gibi göründüğünü, $M B K$ bütün cezaları hafifletmeye karar verdiğinde öbür Ordu grubunun temsilcilerinin idam cezalarının en azından birkaçı infaz edilmezse Komite'nin kararına bakmaksızın hepsini kendilerinin infaz edeceklerini bildirdiklerini söyleyerek devam eder. Ödün gerektiği kabul ediliyordu ve yargıçların sadece dört idam cezasını oybirliğiyle, diğerlerini oy çokluğuyla almalarıyla, uygun bir formül bulundu. Bu dördü, eski Cumhurbaşkanı Bayar'ın ilerlemiş yaşı nedeniyle infaz edilmemesi koşuluyla onaylandı. Dışişleri Bakanı Fatin Rüştü Zorlu'yla Maliye Bakanı Hasan Polatkan 16 Eylül 1961'de, Başbakan Adnan Menderes bir gün sonra asıldı. ${ }^{105}$

103 Zürcher, a.g.e., s. 260-261. Hale, a.g.e., s. 129-131. FO371/163832/CT1011/1, Sir Bernard Burrows, "Annual Report on Turkey for 1961", Britanya Büyükelçiliği, Ankara, 22 Ocak 1962.

104 Göktepe, a.g.m., s. 179.

105 Zürcher, a.g.e., s. 260-261. Hale, a.g.e., s. 129-131. FO371/163832/CT1011/1, Sir Bernard Burrows, "Annual Report on Turkey for 1961", Britanya Büyükelçiliği, Ankara, 22 Ocak 1962.

İki bakan, eski Dışişleri Bakanı Zorlu’yla eski Maliye Bakanı Polatkan 16 Eylül 1962'de İmralı adasında asıldılar. Menderes uyku hapları alarak intihara teşebbüs etti. Hayata döndürüldü ama sonra 17 Eylül'de o da aynı yerde asıldı. Menderes, Zorlu ve Polatkan en sonunda 1990 Eylül'de İstanbul'da devlet töreniyle yeniden gömüldü.

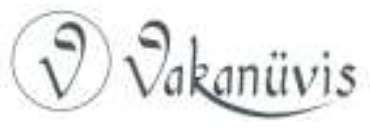


İnfazlara ülkede neredeyse hemen hiç tepki yoktu, "nedeni bir ölçüde infazların sayısının fazla olmamasının verdiği rahatık, bir ölçüde oryantal kadercilik, bir ölçüde Silahlı Kuvvetlerin aleni gösterilere izin vermeyeceğinin açıkça anlaşılmasıydı." ${ }^{106}$ İnfazlara karşı-saldırıda bulunmak yerine, uzun süre hapis cezaları verilen öbür DP üyelerinin kurtulması halkın ve siyasetin daha çok dikkatini çekti. Türkiye'de kararlara ve infazların yapılmasına yurt içinde neden tepki gösterilmediğini sormak önemlidir. İki önemli etken vardı; her şeyden önce sıkıyönetim yürürlükteydi ve sıkı güvenlik önlemleri alındı. Askeri hükümet davayla ilgili bütün kamusal tartışmaları sert cezalar getirerek yasakladı. Halkın Menderes için herhangi bir gösteri yapması, hatta üzülmesi tehlikeliydi. Medya sansürü de vardı. 21 Ağustos'ta iki Türk gazetesi birinci sayfaları sıkıyönetim yetkililerinin son anda sansür uygulaması sonucunda boş olarak çıktı. Haber iki parti lideriyle ilgiliydi, hem Millet Partisi'nin lideri Osman Bölükbaşı hem de Yeni Türkiye Partisi'nin lideri Ekrem Alican demeçlerinde Yassıada'da hiçbir idam cezası verilmemesi gerektiğini açıkça savunmuştu. Daha çok tartışılabilir olan ikinci etken, - Türk halkının karakteriyle ilgiliydi. Britanyalılar Türkleri genellikle "duygularını belli etmeyen insanlar" olarak tanımlarlar. ${ }^{107}$ Doğru olabilir bu ama o tarihte Türkler işçi sendikası veya tarım sendikası gibi sivil kurumlarda, medya kurumlarında veya üniversiteler ve yüksek eğitim kurumları gibi tamamen bağımsız entelektüel kuruluşlarda örgütlü değillerdi. Dolayısıyla, ülkenin genel sessizliği bireylerin gerçekte ne hissettiklerini yansitmıyordu. ${ }^{108}$

\section{Mart 1971 Askeri Muhtırası}

1971 Türkiye'de çalkantılı bir yıldı. Illk aylarda, yılsonunda çözülmeyen birtakım ciddi problemler vardı. Uluslararası düzeyde birkaç ciddi zorluk bulunmakla birlikte, bu problemler genellikle yurt içiyle ilgiliydi. Yine de, Kıbrıs meselesi çözümlenmekten çok uzaktı. ${ }^{109}$

106 FO371/163832/CT1011/1, Sir Bernard Burrows, “Annual Report on Turkey for 1961", Britanya Büyükelçiliği, Ankara, 22 Ocak 1962.

107 The Times, 22 Ağustos 1961.

108 Göktepe, a.g.m., s. 187-188.

109 FCO9/1606/WST1/2, "Turkey: Annual Review for 1971", 1 Ocak 1972. Hale, a.g.e., s. $228-261$.

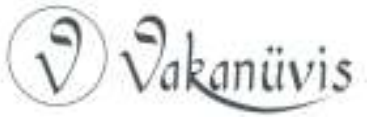


Çok umut bağlanan Demirel yönetimi Ocak'ta atalete gömülmüştü. Kabineyi genelde, karizmatik olmayan, yetenekleri sıradan bakanlar oluşturuyordu, bu durumda Demirel karar hakkını giderek üstlenmişti ama 1970 'de iyi uyguladığı devalüasyon icraatı dışında, problemlerini çözmek gözüne giderek daha az mümkün görünmüştü. Nepotizm ve yolsuzluk suçlamalarına maruz kalmış, kendisine muhalif olan parlamentonun ve silahlı kuvvetlerin çıkarlarının çoğuna yağ sürmüştü. 1961 Anayasası'nın hükümeti etkin ve düzenli hale getiremeyecek kadar çok liberal olduğundan şikâyet ediyordu ama daha sonra önemini kanıtladığı istediği anayasal reformların yapılması için ihtiyaç duyduğu güveni silahlı kuvvetler veya diğer partiler vermedi. Dahası, öğrenci ayaklanmasını bastırmak için sert bir icraatın ardından infaz edilen selefi Menderes'in kaderinin her zaman bilincindeydi. 1960 askeri darbesinin asıl nedeni bu olmamakla birlikte, öğrenci anarşisinin sertlikle üstesinde gelme kararına hafızası her daim ket vuruyordu. ${ }^{110}$

Üniversitelerin çalışmasını aksatan öğrenci başkaldırısı, 1971'in başında uzmanca olan ve muhtemelen dış manipülasyonun işaretlerini veren çok daha ciddi karışıklıklara dönüştü. Aşırı sağcılarla solcuların birbirleriyle ve ikisinin polisle, hatta silahlı kuvvetlerle sık sık silahlı çatışmaları ve bombalı saldırılarıyla, bu karışıklıklar kamu güvenliğini sarstı. Üniversite özerkliğinin abartılı yorumu hükümetin icraatta bulunmasını engelledi, bazı üniversitelerin belediye sınırları dışında, dolayısıyla, polisin yetki sınırları dışında yer alması, örgütlü ve silahlı yıkıcılıkla ve üniversite yerleşkelerinde saklanan büyük silah stoklarıyla baş etmek gibi güç ve hassas bir görev yetersiz eğitim görmüş, cahil acemi jandarmalara bırakıldı. Amerikalı dört havacının kaçırıldığı Mart'ın başında durum dönüm noktasına geldi. Havacılar zarar verilmeden birkaç gün sonra bırakılmakla birlikte, hükümetin genel anarşiye sürüklenmeyi durduracak gücü bulunmadığı belliydi. ${ }^{111}$

1970 yazında İstanbul'daki karışıklıklardan bu yana silahlı kuvvetlerde sürekli huzursuzluk işaretleri ve Mart'ın ilk günlerinde silah zoruyla bir askeri darbe başlatmak için ciddi bir girişim yapıldığının

110 FCO9/1606/WST1/2, “Turkey: Annual Review for 1971", 1 Ocak 1972. Hale, a.g.e., s. $228-261$.

111 FCO9/1606/WST1/2, “Turkey: Annual Review for 1971", 1 Ocak 1972. Hale, a.g.e., s. $228-261$.

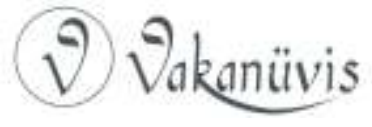


güçlü bir kanıtı vardı. Darbe başarısız oldu, çünkü tedirgin subaylar savaş birliklerine komuta edemediler: Halefleri hareketi reddetmekle kalmadılar, Genelkurmay Başkanı'na da bildirdiler. Genel tatminsizliği kuşkusuz Demirel hükümetiyle paylaşan Genelkurmay Başkanı ve Kuvvet Komutanları bu gelişmeyle harekete geçtiler. Düzeni yeniden sağlamak, Atatürk'ün politikasına ve ideallerine uygun reformlar yapmak için hemen yeni bir "partiler üstü" hükümet kurulmasını talep ederek 12 Mart'ta bir muhtıra gönderdiler. Generaller parlamenter hükümet bu görevleri yapamazsa hükümeti devralmakla tehdit ettiler. Demirel aynı gün istifa etti. ${ }^{112}$

Bu krizin ve yılın geri kalanının özelliği sivil Devlet Başkanı ama emekli Genelkurmay Başkanı olan Cumhurbaşkanı General Sunay'ın oynadığı önemli ve yararlı roldü. Komutanlar Sunay'a ve hükümetine dikte etmeye yeltenmişler ve muhtıralarını tartışma çağrısına uymayı ilkin kabul etmemişlerdi. Cumhurbaşkanının istifa tehdidi karşısında komutanlar boyun eğdiler ve bir uyuşma çözümünde mutabık kalındı. Seçkin anayasa hukuku profesörü Nihat Erim'den hükümet kurması istendi. İstifa ettiği Cumhuriyet Halk Partisi'nin hayli yetenekli ve saygın, ılımlı bir üyesi olan Nihat Erim sözü geçen koşullarda neredeyse herkesin kabul edeceği adaydı. En büyük dört partinin üçünden aldığı ama çoğunluğu parlamento dışında "teknokratların" oluşturduğu bir hükümet kurdu. ${ }^{113}$

Aynı zamanda, üst rütbeli komutanlarla bakanlardan oluşan, cumhurbaşkanının başkanlığındaki Milli Güvenlik Konseyi'nin önemi Erim hükümetiyle Türk genelkurmayı arasında böyle sürdürülecek çok yakın işbirliğinin aracı olarak giderek arttı. 1960'dan sonra askerin doğrudan yönetiminin mutsuz hatıralarıyla, ordu, siyasetin yakın denetimini Konsey'le ve Cumhurbaşkanı'yla şahsi teması aracılığıyla sürdürürken hükümeti sivillere bırakmaktan çok hoşnuttu. ${ }^{114}$

112 FCO9/1606/WST1/2, "Turkey: Annual Review for 1971", 1 Ocak 1972. Hale, a.g.e., S. $228-261$.

113 FCO9/1606/WST1/2, “Turkey: Annual Review for 1971", 1 Ocak 1972. Hale, a.g.e., s. $228-261$.

114 FCO9/1606/WST1/2, "Turkey: Annual Review for 1971", 1 Ocak 1972. Hale, a.g.e., s. $228-261$.

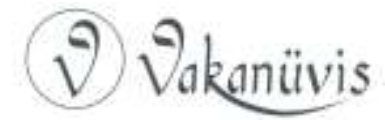


Erim hem radikal bakış açılarıyla iyi tanınan daha genç bakanlar atayarak hem de sol görüşlü bir reform programı açıklayarak militan sola sekte vurma umuduyla iktidara geldi. Bir süre bu başarı vaat eder gibi göründü ama ortaya çıkan yıkıcılığın ciddiliği ve kapsamı 26 Nisan'da 11 ilde sıkıyönetim ilan edilmesini gerektirdi. Ne var ki en dikkat çekeni Mayıs ayında İsrail'in İstanbul Başkonsolosu'nun kaçırılması olmak üzere devam eden karışıklık, yeni hükümete reformları sonuçlandıracak yeterli zaman tanımadı ve politika değişikliğini dikkate almayan, etkilenmeyecek olan örgütçülerin çekirdek kadrosunun varlığını ortaya koydu. Bu nedenle, Erim yıkıcılara karşı doğrudan harekete geçme adına reformu ertelemek, anayasa reformunu ve ilkin ekonomik önlemler almayı umduğu durumu yönetme hakkını kararnameyle almak zorunda kaldı. ${ }^{115}$

Kamu düzenine yoğunlaşma önemli başarılar getirmeye başladı. Kamuya saldırılar ve gösteriler kesildi, üniversiteler sinmekten kurtularak yeniden çalışmaya döndü. Anayasa reformları, ne gariptir ki daha önce Demirel'le AP'nin belirlediği çizgilerde onaylandı. Parlamentoda aylarca tartıştıktan sonra yürütme organı yasama organının elinde tuttuğu eski aşırı denetim ve engelleme mekanizması karşısında daha büyük güç elde etti. Ne var ki kararnameyle yasa çıkarma artık anayasaya aykırı olmamakla birlikte, Millet Meclisi reform programını sağlayan gerekli yasayı çıkarmakta isteksizdi. Bu sınırlı başarı ve kamu güvenliğinin ulusal önceliklerin ilk sırasından kaldırılması Erim hükümetinin yapısının özünde var olan anlaşmazlıkları ortaya koydu. ${ }^{116}$

Radikal teknokratlar ordunun 12 Mart tarihli muhtırasına ve sözde Atatürk ilkelerine işaret ederek, öncelik toprak reformuna verilmek üzere reform talep ettiler. Parlamentoda hâlâ çoğunluğu oluşturan AP, özellikle kendi muhafazakâr ilkelerine taban tabana zıt olan hükümetin toprak reformu programına muhalefetini açıkladı. Büyük ihtimalle parti liderleri gelecekteki bir seçimde destekçilerinin gözündeki güvenilirliğini yakından izliyordu. Erim'le Demirel'in arasındaki ilişkiler

115 FCO9/1606/WST1/2, "Turkey: Annual Review for 1971", 1 Ocak 1972. Sina Akşin (Yay. Yön.), Türkiye Tarihi: Çağdaş Türkiye, 1908-1980, İstanbul, 2002, s. 260-269.

116 FCO9/1606/WST1/2, "Turkey: Annual Review for 1971", 1 Ocak 1972. Akşin, a.g.e., s. $260-269$.

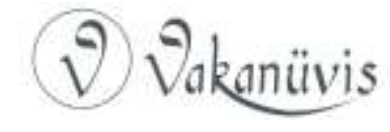


hızla bozuldu ve AP 5 Ekim'de hükümetten beş bakanını çekti, AP'nin haksız eleştiriler karşısında "partiler üstü" tutumundan vazgeçtiğini gösteriyordu bu. Kriz Kraliçe'nin 18 Ekim'deki ziyareti nedeniyle askıya alındı. Bundan sonra, 26 Ekim'de Erim daha önce böyle bir durumda yapacağını söylediği tehditlerine sadık kalarak istifa etti. Perde arkasında birçok pazarlıktan sonra sonunda istifasını geri almaya ve AP'li bakanların hükümette kalmasına izin vermeye ikna edildi, ikisi de ulusal çıkar adınaydı. Geçici bir rahatlama yaşandı ama çok geçmeden krizin çözülmekten çok uzak olduğu anlaşıldı. ${ }^{117}$

Erim, herhangi bir ilerleme kaydetmek için AP'yle uzlaşması gerektiğini anladı. Çabaları, 2 Aralık'ta Demirel'in eski hükümetinin bir üyesini, Ali Mesut Erez, "Parlamentoyla ilişkilerden özel sorumlu" olarak üçüncü Başbakan yardımcılı̆ıına atanmasıyla sonuçlandı. Ertesi günü, bakanlarının $11^{\prime} i$ istifa etti. En önemli teknokratlar onlara dâhildi, her biri az çok radikal eğilimliydi, esaslı bir reform programını yürürlüğe koyabilecekleri anlayışıyla hükümete katıldıklarını ama bunun besbelli imkânsız olduğunu belirttiler. Görev tanımını yanlış anlamış ve demokrasinin geçerli olması için parlamentoyla çalışmak zorunda olduklarını anlamamış olabilirlerdi. Bir ihtimal, çıkar gruplarının onları kasten engellediği şikâyetlerinde de haklıydılar. Davranışlarının, askerin kontrolü ele geçirmesini tetiklemesini beklediklerinden çok kuşku duyuluyordu, radikal ve milliyetçi programlarının Millet Meclisi'ni hesaba katmadan kararnameyle yürütülmesini sağlayacaktı bu. ${ }^{118}$

Radikaller ordunun ruh halini yanlış hesapladılar. Generaller kendi radikal kanadında avantaj sağlamış, radikal ekonomik reformlarında eski ısrarı azaltmış gibi görünüyorlardı. Erim beklendiği gibi istifa etti ama yeniden hükümet kurmaya çağrıldı. Sol anarşinin yakında patlak verme tehlikesinden ve solu sakin tutmaları artık gerekmeyen solcu bakanlardan kurtulan Erim daha merkezi bir tutum takınabilir ve Millet Meclisi'nin ruh haline daha yaklaşabilirdi. Şimdi 25 bakandan 11 'i kalan "teknokratlar" daha az radikal ve doktriner görünürken,

117 FCO9/1606/WST1/2, “Turkey: Annual Review for 1971", 10cak 1972. Akşin, a.g.e., S, . 260-269.

118 FCO9/1606/WST1/2, "Turkey: Annual Review for 1971", 1 Ocak 1972. Akşin, a.g.e., s. $260-269$.

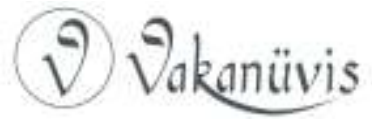


parlamenterler çoğunluktaydı. Yeni programda reformlar konusu muğlaktı ve programın ülkenin problemlerine daha pragmatik yaklaşımına, hükümetle politikayı tartışmaya davet edilen iş camiasıyla ilişkileri düzeltmek için açık bir girişim gözüyle bakılıyordu. Devlet müdahalesi ve "en iyi ulusal çıkardan yararlanma" fikrinin yerine "devletleştirme" yi koyma ısrarı daha azdı. ${ }^{119}$

Mart'ta kamu düzeni krizinin başında öne sürülen daha önceki aceleci reform programına 1971 olayları daha çok gerçekçilik kattı. Atatürk devriminin askeri ve entelektüel mirasçıları gönülsüz bile olsa artık daha aşamalı reformları kabul etmiş ve demokrasiyi gerekli çerçeve kabul ederek seçilmiş parlamentonun koyduğu sınırları tanımış görünüyorlardı. Yine de tatminsiz ve sabırsızdılar, parlamentonun muhalefet ettiği reformları uygulamak için seçim reformundan ve etkili yöntemlerden söz ediyorlardı. Türkiye'de her zaman olduğu gibi, ordu bu huzursuz denge durumunda kilit konumdaydı. Generaller hem doğrudan iktidardan kaçınmak hem de sıkıyönetim yüküne ellerinden geldiğince çabuk son vermek istiyorlardı. Denetimli demokrasi sistemi 1973 seçimlerine kadar sürdü. ${ }^{120}$

\section{Eylül 1980 Askeri Darbesi}

1980, "askerin kontrolü üçüncü kez ele geçirdiği" yıl olarak hatırlanacaktır. Merkezi hükümetin sendeleyen otoritesiyle şiddet olayları ordunun 12 Eylül'de müdahalesine zemin hazırladı. Şiddet olayları belli yerlerdeydi ve halkın büyük çoğu doğrudan etkilenmiyordu, ülkenin iç savaşın eşiğine geldiğini iddia edebilmek zordu. Yine de, şiddeti körükleyenlerin amacı mevcut düzeni bozmak, ya sağın ya da solun diktatörlüğünü oluşturmaktı. Şiddet ne kadar uzun sürerse böyle bir gelişmenin meydana gelme riski o kadar büyüktü. Generaller demokrasiyi değil, işlevini görmesinin önündeki engeller ortadan kaldırmak için müdahale ettiklerini öne sürdüler. Bütün ülke onlara inandı ve icraatlarını iç rahatlığıyla karşıladı. ${ }^{121}$

119 FCO9/1606/WST1/2, "Turkey: Annual Review for 1971", 1 Ocak 1972. Akşin, a.g.e., s. $260-269$.

120 FCO9/1606/WST1/2, "Turkey: Annual Review for 1971", 1 Ocak 1972. Akşin, a.g.e., s. $260-269$.

121 FCO9/3317/WST014/2, "Turkey: Annual Review for 1980", 28 Ocak 1981. Akşin, a.g.e., s. 269-280. Hale, a.g.e., s. 261-352.

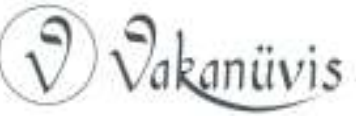


Düzenin yeniden sağlanması neredeyse mucize gibiydi. Adam öldürme oranı günde ondan bire, ikiye düştü. Gecekondu beldeleri ve üniversiteler yeniden huzura kavuştu. Hem sol hem de sağ çetelere karşı aktif operasyonlar yapıldı. Binlerce sanık tutuklandı, davalar başladı, suçu sabit görülen dört terörist asıldı. Çok miktarda silah teslim edildi veya ele geçirildi. Yetkililer kesin bir zafer değilse de, ilk raundu kazanmışlardı. Sağcılar ciddi bir darbe aldılar ama solun hâlâ bir çekirdek kadrosu vardı. Poliste ve yönetimde kutuplaşmayı gidermeyi sağlama alacak yavaş süreç henüz başlamıştı. ${ }^{122}$

General Evren ve dört Kuvvet Komutanı yeni Milli Güvenlik Konseyi'ni kurdu, önemli bir sorumluluk aldılar. Parlamento'yu dağıtıp Anayasa'nın bazı maddelerini askıya alarak General Evren'i Devlet Başkanı, kendilerini de tek yasama organı atadılar. Eski Parlamento'dan geçemeyen yasa tasarılarını geliştirmeyi özenle ele aldılar. Yürürlüğe koyulacak ilk yasalar güvenliğin üstesinden gelmek için acil durum süreçlerini belirleyen yasalardı. Sınırlarını anlayan generaller Demirel'in başlattığı ekonomi politikaya devam ettiler, mimarı olan Turgut Özal'ı bunu yürütmekle görevlendirdiler. Özal, dış yardımın cömertçe sağlanmaya devam edileceği varsayımıyla, ekonomiyi rayına oturtmanın Türkiye'nin 4-5 yılını alacağını öngörüyordu. ${ }^{123}$

Öte yandan, 12 Eylül'ün ardından siyasal partiler yasaklandı. Merkeziyetçi federasyonu oluşturan Türk-iş dışında, aşırılık yanlısı işçi sendikalarının ve Türk-İngiliz Kültür Derneği dışında herhangi bir siyasal eğilimi bulunan bütün derneklerin faaliyetleri askıya alındı. Gazeteler özgür bırakıldı ama kendi sansürlerini kendilerinin uygulamaları beklendi. İşkence iddialarına ve gözaltında ölenlerle ilgili raporlara göre, Güvenlik Güçleri acımasız davranıyordu. Bu raporlar yayınlandı, soruşturmalar başladı, adı karışan Güvenlik Güçleri'nin üyeleri açığa alındı veya tutuklandı. ${ }^{124}$

122 FCO9/3317/WST014/2, "Turkey: Annual Review for 1980", 28 Ocak 1981. Akşin, a.g.e., s. 269-280. Hale, a.g.e., s. 261-352.

123 FCO9/3317/WST014/2, "Turkey: Annual Review for 1980", 28 Ocak 1981. Akşin, a.g.e., s. 269-280. Hale, a.g.e., s. 261-352.

124 FCO9/3317/WST014/2, "Turkey: Annual Review for 1980", 28 Ocak 1981. Akşin, a.g.e., s. 269-280. Hale, a.g.e., s. 261-352.

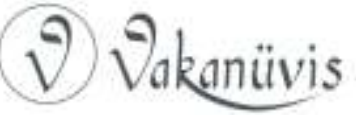


Generaller düzen bir kez daha yeterince sağlandığında normale nasıl dönüleceğini de düşünmeliydiler. Generallerin süresiz kalmak isteyeceklerini kimse sanmıyordu. 1960'da ve 1971'de vaatlerini tutmuşlardı. Ne var ki bu sefer hem düzeni yeniden sağlamayı hem de anayasayla seçimler ve siyasal partilerle ilgili yasaları düzeltmeyi ve bunu gelecekte partili siyasetçilerin kuralları değiştiremeyecekleri tarzda yapmayı kendilerine görev edindiler. Bu arada, 21 Eylül'de ülkenin olağan yönetimi sivil hükümetin eline bırakıldı. Üyelerinin çoğu eski amiraller ve generallerdi ama Özal Başbakan Yardımcısı olarak dâhil edildi, Dışişleri Bakanı diplomat, Sanayi ve Teknoloji Bakanı saygın bir işadamı, Sosyal Güvenlik Bakanı Türk-iş'in genel sekreteriydi. Anayasa'yı düzeltme çalışması başladı, General Evren 15 Ocak 1981'de Konya'da yaptığı konuşmada her şey düzgün giderse Kurucu Meclis'in 30 Ağustos'la 29 Ekim 1981 arasında toplanacağını duyurdu. ${ }^{125}$

Hem Demirel hem generaller dönemlerinde dış siyasette Doğu Avrupa'dan veya Üçüncü Dünya'dan çok Batı'yla ilişkiler vurgulandı. 12 Eylül'den sonra Kuzey Atlantik Paktı ve Avrupa Konseyi'ne bağlıık yeniden teyit edildi. Avrupa Topluluğu'yla ilişkiler daha önce yeniden aktif hale getirilmişti. Birlik Sözleşmesi gözden geçirildi, geliştirildi ve eski Dışişleri Bakanı yıl sona ermeden önce Topluluğa üyelik başvurusu yapılmasından söz etti. Bunun motivasyonu, Yunanistan 1 Ocak 1981 'de tam üye olarak topluluğa katılmadan önce resmi başvuruda bulunma arzusuydu. Askerin kontrolü ele geçirmesi bunun ertelenmesine neden oldu. Aynı zamanda Yunanistan'la ilişkiler yıl içinde ilerletildi, Türkler Şubat'ta NOTAM 714'ü tek taraflı kaldırarak ilk adımı attılar, dolayısıyla, Ege'de sivil havacılığın yeniden başlamasının yolu açıldı. Türkiye'nin uzlaşma prosedürünü kabul ettiğini Müttefik Yüksek Komutanı'nı Ekim'de imzaladı, Avrupa Yunanistan'ın NATO'nun askeri yapısına yeniden katılmasını sağladı. Ankara'nın Kıbrıs konusunda Denktaş'a baskısı NATO'nun gözetiminde toplumlar arası görüşmelerin, biraz ilerleme umuduyla birlikte yeniden başlamasında yararlı oldu. ${ }^{126}$

125 FCO9/3317/WST014/2, "Turkey: Annual Review for 1980", 28 Ocak 1981. Akşin, a.g.e., s. 269-280. Hale, a.g.e., s. 261-352.

126 FCO9/3317/WST014/2, "Turkey: Annual Review for 1980", 28 Ocak 1981. Akşin, a.g.e., s. 269-280. Hale, a.g.e., s. 261-352.

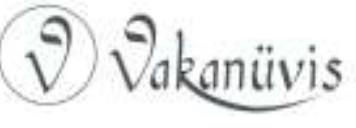


İran devrimi Türkiye'yi etkilememekle birlikte Türkiye hem bu ülkedeki gelişmelerle hem de Sovyetlerin Afganistan'ı işgal etmesinin bölge istikrarını tehdit etmesiyle çok ilgiliydi. Irak/İran savaşı Türkiye'yi başka bir ikilemle karşı karşıya getirdi, çünkü Türkiye petrol taleplerinin büyük bölümünü sağladığı ve ihracatı için değerli birer pazar olan iki ülkeyle de ilişkilerinin iyi olmasını istiyordu. Türkiye İslam ülkelerinin Sovyetlerin Afganistan'ı istilasına muhalefetini açıklarken, Sovyetlerin tepkisini kendi üzerine çekecek kadar ileri gitmeden başrolü oynadı. Iran/Irak çatışmasında Türkiye iki tarafla da ilişkisini sürdürdü ama tarafsız duruşunu alenen korumaya dikkat etmişti. ${ }^{127}$

Batı'yla ilişkilerde küçük ama potansiyel olarak önemli iki olumsuz etken belirdi, bunun dışında iyi gidiyordu. Biri, Benelüks ülkeleriyle Fransa'nın ardından Almanya Federal Cumhuriyeti'nin de Türklere yeniden vize koymasıydı. Nedeni, Almanya'nın siyasal sığınma yasalarının liberalliğinden yararlanan göçmen işçi akınını denetleme ihtiyacıydı. Türkler bunu anlamakla birlikte ayrımcılık diye baktılar, gururları kırıldı, örtük yabancı düşmanlıkları ortaya çıktı. íkinci neden, Türklerin, özellikle İskandinav ülkelerinin ve Avrupa Konseyi'nin belirttiği demokrasiye dönüş hızlarına yurt dışının abartılı ilgisi diye bakmasıydı. Türkler kendi meselelerini şiddetle tartışıyorlardı ama işlerini nasıl yapacakları söylendiğinde güceniyorlardı. ${ }^{128}$

Britanya'nın bakış açısı, Türkiye'nin Kuzey Atlantik Paktı'nın sağlam bir üyesi olması, koşullar ve kaynaklar elverdiğince Doğu Akdeniz'de yapıcı bir rol oynaması ve ekonomik açıdan kendi ayakları üzerinde durabilmesi gerektiği yönündeydi. Türkler Britanya'nın maddi yardım sağlama gücünün sınırlarını kabul ediyorlardı. Aslında, kendi durumlarıyla bazı benzerlikler Britanya'yla Türkiye arasında bir bağ yaratıyordu. Britanya'nın, biraz az olmasına rağmen para yardımını ve Türkiye'nin Britanya'ya borçlarını ödemesinin ertelenmesini takdirle karşıladılar. Ne var ki Türklerin Britanya'dan kazanımları, paradan çok, Britanya'nın uluslararası işlerde daha deneyimli olması, Britanya hükümetinin o tarihte hâlâ nüfuzunu kullanması, Türkiye'yle ciddi

127 FCO9/3317/WST014/2, "Turkey: Annual Review for 1980", 28 Ocak 1981. Akşin, a.g.e., s. 269-280. Hale, a.g.e., s. 261-352.

128 FCO9/3317/WST014/2, "Turkey: Annual Review for 1980", 28 Ocak 1981. Akşin, a.g.e., s. 269-280. Hale, a.g.e., s. 261-352.

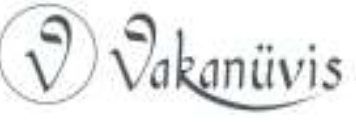


görüş alışverişinde bulunmaya hazır olmasıydı. 1980'de Britanya'nın hedeflerine varması doğrultusunda bu kazanımlardan verimli şekilde yararlanıldı. ${ }^{129}$

1981 Atatürk yılıydı. Selanik'te doğuşunun yüzüncü yılı bir şekilde zaten kutlanacakken kontrolü ele geçiren asker ona artı önem verdi. Selefleri gibi, 1980 darbesi de yeni bir ideoloji dayatma girişimi değil, eksikliklere ve kötüye kullanmalara karşı tepkiydi. Generaller geriye bakıyorlar, Atatürk'ü rehber kabul ediyorlardı. Neyse ki Atatürk'ün felsefesi aslında dogmatik değil, pragmatikti. Illkesi bağımsızlık, özgüven ve bütün ülkelerle barışçl işbirliğiydi. General Evren'in bizzat sık sık vurguladığı gibi, Atatürk de Silahlı Kuvvetlerin siyasetin dışında kalmasında ısrarlıydı. ${ }^{130}$

\section{Sonuç}

Türk Silahlı Kuvvetleri 20. yüzyılda ulusun siyasal gelişmesinde açıkça çok önemli rol oynadı. Ordunun, desteğiyle önemli unsurlardan birini oluşturduğu istiklal Savaşı zaferinin ardından Cumhuriyet kuruldu. Atatürk, rejimini güvence altına aldı, geniş kapsamlı reform programı geliştirdi ve ülkeyi istikrarlı duruma getirdi, vurguyu askeri iktidardan sivil iktidara çevirebildi. Türkiye'nin o sıralarda dış tehdit altında bulunmadığını bilerek, dikkatini ülkenin ekonomik ve sosyal yapısını modernleştirmeye, geliştirmeye ve Batılılaştırmaya verdi, Silahlı Kuvvetlerin ihtiyaçları doğrultusunda göreli az çaba gösterdi. Genelde asker Atatürk'ün ve onun 1938'de ölümünden sonra bu süreci 12 yıl sürdüren halefi İnönü’nün arkasında sebatla durdu.

1950'den 1960'a kadar DP, izlediği ekonomik ve siyasi politikalarla ve demokratik süreçleri hiçe saymasıyla, Atatürk'ün modernleşme ve Batılılaşma ideallerinden giderek ayrıldı. Üstelik Silahlı Kuvvetlerin görüşünü yok saydı, gerek subay sınıfının maddi durumunu, gerekse zamanı geçmiş askeri donatımı düzeltemedi. 1960 darbesi, askerin aktif olarak öncülük ettiği, çoğunluğunu ulusun eğitimli sınıflarıyla entelektüel kesiminin oluşturduğu radikal azınlık için zaferi temsil

129 FCO9/3317/WST014/2, "Turkey: Annual Review for 1980", 28 Ocak 1981. Akşin, a.g.e., s. 269-280. Hale, a.g.e., s. 261-352.

130 FCO9/3317/WST014/2, "Turkey: Annual Review for 1980", 28 Ocak 1981. Akşin, a.g.e., s. 269-280. Hale, a.g.e., s. 261-352.

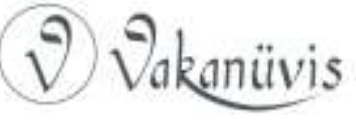


ediyordu ama DP’nin görev süresini demokrasi dışı yollarla süresiz uzatma niyeti güttüğü kesinlikle belli olduğunda asker darbeye girişti. Darbe Atatürk'ün hedeflerini ve ideallerini yeniden tesis etme, daha dengeli ve eşitlikçi bir ekonomik büyümeyi başlatma girişimiydi. Silahlı Kuvvetlerin siyasete doğrudan müdahale dönemi sınırlıydı ama daha sonraki yıllarda Silahlı Kuvvetlerle siyasetçiler arasında daha yakın teması sağladı ve Silahlı Kuvvetler dâhil, eğitimli Atatürkçü burjuvazi işlerin yürütülmesinde eskisinden daha çok söz sahibi oldu.

Silahlı Kuvvetler siyasal nüfuzunu Atatürk ilkelerinin sürdürülmesi olarak düşündükleri olguya yönlendirdi. Bunun anlamı planlı ekonomik büyümeyi, sosyal adalet ilkelerini ve siyasal, teknik, ticari ve eğitim kurumlarını Batı demokrasilerini örnek alarak desteklemekti. Atatürk'ün, devlette sivillerin üstünlüğü geleneğini de kapsıyordu. Subayların az bir oranı askeri hükümetten yana olmaya kuşkusuz devam ediyordu ama o tarihteki kanıtlara göre, onların görüşleri geniş ölçüde paylaşılmıyordu ve Silahlı Kuvvetlerle siyasetçilerin temasının artması askeri müdahale ihtimalini azaltıyordu. Yine de Atatürkçü Cumhuriyet'in bazı temel ilkeleri sürdürüldü, bundan ciddi ödün vermek doğrudan askeri müdahaleyi davet ederdi. Bu ilkeler (ilk Anayasa'da ve 1961 Anayasası'nda ifade edildiği üzere) demokrasinin korunması, halkın kitle halinde ekonomik ilerleme kaydetmesi, Türkiye'nin özellikle Kıbrıs konusunda uluslararası prestijinin sürdürülmesi merkezine oturtuldu. Gelecekte bir askeri müdahalenin en muhtemel nedeni, düzenin geniş bazda bozulmasına yol açan ciddi ekonomik başarısızlık, tırmanan enflasyon ve (özellikle örgütlü sanayi iş̧ileri arasında) işsizlik olurdu. Yine de sonuçta, 1960'ların sonunda Siyahlı Kuvvetlerin yakın gelecekte demokratik yoldan seçilmiş bir sivil hükümetin yerini almaya yönelmeyeceği ortaya çıktı.

Mart'ta kamu düzeni krizinin başında öne sürülen daha önceki aceleci reform programına 1971 olayları daha çok gerçekçilik kattı. Atatürk devriminin askeri ve entelektüel mirasçıları gönülsüz bile olsa artık daha aşamalı reformları kabul etmiş ve demokrasiyi gerekli çerçeve kabul ederek seçilmiş parlamentonun koyduğu sınırları tanımış görünüyorlardı. Yine de tatminsiz ve sabırsızdılar, parlamentonun muhalefet ettiği reformları uygulamak için seçim reformundan ve etkili yöntemlerden söz ediyorlardı. Türkiye'de her zaman olduğu gibi, ordu

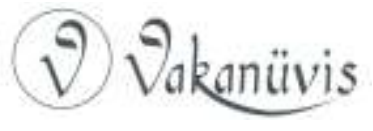


bu huzursuz denge durumunda kilit konumdaydı. Generaller hem doğrudan iktidardan kaçınmak hem de sıkıyönetim yüküne ellerinden geldiğince çabuk son vermek istiyorlardı. Denetimli demokrasi sistemi 1973 seçimlerine kadar sürdü.

Selefleri gibi, 1980 darbesi de yeni bir ideoloji dayatma girişimi değil, eksikliklere ve kötüye kullanmalara karşı tepkiydi. Generaller geçmişe bakıp Atatürk'ü rehber kabul ediyorlardı. Neyse ki Atatürk'ün felsefesi aslında dogmatik değil, pragmatikti. İlkesi bağımsızık, özgüven ve bütün ülkelerle barışçıl işbirliğiydi. General Evren'in bizzat sık sık vurguladığı gibi, Atatürk de Silahlı Kuvvetlerin siyasetin dışında kalmasında ısrarlıydı.

1981'de modern Türkiye'nin kurucusu birçok resmi törenle anılırken Atatürk ilkelerinin, Türk Silahlı Kuvvetlerinin otoritesinin ve Türk halkının sağduyusunun birleşmesinin, Türklerin demokrasi deneyiminin bir sonraki aşamasına hazırlanmaları için yeterli olup olmayacağı görülecekti.

\section{Kaynakça}

\section{Arşiv kaynakları}

Bu makale bir dizi birincil ve ikincil kaynağa dayanmaktadır. Araştırma malzemesinin çoğu Birleşik Krallık'ın Ulusal Arşivleri'nden (The National Archives-TNA) derlenmiştir. Başında FO ve FCO ekleri bulunan kaynaklara göndermeler, eski Devlet Arşivleri Kurumu (Public Record Office-PRO), günümüzün Birleşik Krallık Ulusal Arşivleri'nde yer alan belgeleri belirtmektedir. Çalışmada aşağıdaki belgelere başvurulmuştur: FO371/136452, FO371/136450, FO371/130174, FO371/123999, FO371/163832, FO371/160212, FO371/95267, FO371/101848, FO371/107547, FO371/112921, FO371/144739, FO371/153030, FO371/117717, FO371/117718.

\section{Kitaplar \& Makaleler}

AHMAD, Feroz, Demokrasi Sürecinde Türkiye, 1945-1980, (Çev. Ahmet Fethi), İstanbul, 1996.

AHMAD, Feroz, Modern Türkiye'nin Oluşumu, (Çev. Yavuz Alogan), İstanbul, 1994.

AHMAD, Feroz, The Making of Modern Turkey, London, 1993.

AKŞiN, Sina (Yay. Yön.), Türkiye Tarihi 4: Çağdaş Türkiye, 1908-1980, istanbul, 2002.

AKŞiN, Sina, Kısa Türkiye Tarihi, İstanbul, 2007.

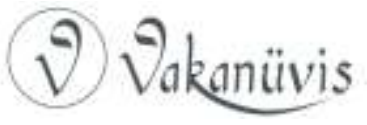


ALKAN, Mehmet Ö, Osmanlı'dan Günümüze Darbeler, İstanbul, 2017. ARCAYÜREK, Cüneyt, Darbeler ve Gizli Servisler, Ankara, 1990. AYDEMIR, Şevket Süreyya, ikinci Adam, C. III, İstanbul, 1968. AYDEMiR, Şevket Süreyya, Menderes'in Dramı, İstanbul, 1998. AYDEMIR, Talat, Talat Aydemir'in Hatıraları, İstanbul, 1968. BAĞCl, Hüseyin, Demokrat Parti Dönemi Dış Politikası, Ankara, 1990. BiRAND, Mehmet Ali, vd., Demirkırat: Bir Demokrasinin Doğuşu, İstanbul, 1991.

EROĞUL, Cem, Demokrat Parti: Tarih ve ideolojisi, Ankara, 1998. 2014.

HALE, William, Türkiye'de Ordu ve Siyaset, (Çev. Ahmet Fethi), İstanbul,

KARPAT, Kemal, Türk Demokrasi Tarihi (Sosyal, Ekonomik ve Kültürel Temeller), İstanbul, 1967.

KARPAT, Kemal, Osmanlı'dan Günümüze Asker ve Siyaset, i̇stanbul, 2015. KAYALI, Kurtuluş, Ordu ve Siyaset (27 Mayıs-12 Mart), i̇stanbul, 2018.

KURT, Veysel, Ortadoğu'da Ordu ve Siyaset, Ankara, 2018.

LENCZOWSKI, George, The Middle East in World Affairs, New York, 1990.

ÖKE, Mim Kemal, Din-Ordu Gerilimi, İstanbul, 2002.

ÖZDAĞ, Ümit, Atatürk ve Inönü Dönemlerinde Türk Silahlı Kuvvetleri, Ankara, 2017.

ÖZDAĞ, Ümit, Menderes Döneminde Ordu-Siyaset Iliş̧kileri ve 27 Mayıs ihtilali, İstanbul, 1997.

TOKER, Metin, Demokrasimizin ismet Paşa'lı Yılları, 1944-1973: Demokrasiden Darbeye, 1957-1960, Ankara, 1991.

TOKER, Metin, Demokrasimizin ismet Paşa'lı Yılları, 1944-1973: DP'nin Altın Yılları, 1950-1954, Ankara, 1991.

TOKER, Metin, Demokrasimizin Ismet Paşa'lı Yılları, 1944-1973: DP Yokuş Aşağı, 1954-1957, Ankara, 1991.

TOKER, Metin, Demokrasimizin ismet Paşa'lı Yılları, 1944-1973: Yarı Silahlı, Yarı Külahlı Bir Ara Rejim, 1960-1961, Ankara, 1991.

TÜRKEŞ, Alpaslan, 27 Mayıs, 13 Kasım, 21 Mayıs Gerçekler, İstanbul, 1977. WIEKER, Walter F., 1960 Türk ihtilali, (Çev. Mete Ergin), İstanbul, 1967.

YETKIN, Çetin, Türkiye'de Askeri Darbeler ve Amerika, Antalya, 2007.

ZÜRCHER, Erik J., Turkey: A Modern History, Londra, 1995. 